\title{
Public Initiatives of Settlement Transformation: A Theoretical-Methodological Approach to Selecting Tools of Multi-Criteria Decision Analysis
}

\author{
Maria Rosaria Guarini * (D), Fabrizio Battisti and Anthea Chiovitti \\ Department of Architecture and Design, Sapienza University of Rome, Via Flaminia 359, 00196 Rome, Italy; \\ fabrizio.battisti@uniroma1.it (F.B.); anthea.chiovitti@uniroma1.it (A.C.) \\ * Correspondence: mariarosaria.guarini@uniroma1.it; Tel.: +39-06-4991-9293
}

Received: 3 August 2017; Accepted: 18 December 2017; Published: 22 December 2017

\begin{abstract}
In Europe, the operating context in which initiatives of settlement transformation are currently initiated is characterized by a complex, elaborate combination of technical, regulatory and governance-related factors. A similar set of considerations makes it necessary to address the complex decision-making problems to be resolved through multidisciplinary, comparative approaches designed to rationalize the process and treat the elements to be considered in systematic fashion with respect to the range of alternatives available as solutions. Within a context defined in this manner, decision-making processes must often be used to obtain multidisciplinary and multidimensional analyses to support the choices made by the decision-makers. Such analyses are carried out using multi-criteria tools designed to arrive at syntheses of the numerous forms of input data needed to describe decision-making problems of similar complexity, so that one or more outcomes of the synthesis make possible informed, well thought-out, strategic decisions. The technical literature on the topic proposes numerous tools of multi-criteria analysis for application in different decision-making contexts. Still, no specific contributions have been drawn up to date on the approach to take in selecting the tool best suited to providing adequate responses to the queries of evaluation that arise most frequently in the various fields of application, and especially in the settlement sector. The objective of this paper is to propose, by formulating a taxonomy of the endogenous and exogenous variables of tools of multi-criteria analysis, a methodology capable of selecting the tool best suited to the queries of evaluation which arise regarding the chief categories of decision-making problems, and particularly in the settlement sector.
\end{abstract}

Keywords: multi-criteria decision analysis (MCDA); decision-making (DM); Life Cycle Management

\section{Introduction and Aims of the Work}

The complexity of settlement transformation processes (technical, regulatory, related to governance) generates, in the course of the procedural approaches addressing them, decision-making problems characterized by the multidimensional profiles of their objectives and by the multidisciplinary or multi-criteria nature of the factors to be evaluated. To manage similar decision-making problems during the different phases of the construction process, use must be made of methodologies of evaluation designed to interpret and translate, at varying levels of depth and elaboration, the intent of a given effort with respect to the transformation of the territory.

Processes for the strategic planning of decisions implemented through decision support systems (DSS) [1] prove highly effective when dealing with settlement transformations. DSS have also been developed with computerized systems that make possible an interactive use of data and models to support decision-makers as they solve problems. In each of the iterative and interactive phases of the construction process cycle, strategic planning regarding decisions is geared towards arriving 
at informed choices by drawing on the methods of evaluation best suited to the purpose at hand and to the framework of needs and demands to be met by the programs and projects undertaken in the territory.

Within DSS, the use of tools of multi-criteria decision analysis (MCDA) can provide support for the management of the multidisciplinary nature of the considerations and factors to be simultaneously optimized in fulfilling the evaluation objective [2]. The literature on MCDA count different schools of thought $[3,4]$ proposing an extensive number of tools for solving decision-making problems in fields of application that include mathematics, management, information technology, psychology, the social sciences and economics. Especially in the last decade, in urban settlement transformations, the interest in application of formalized decision-analytical tools with structured and complete database increased [5]. Different decision-making problems have garnered great interest: (i) environmental problems such as waste management, water quality management [6], emissions, energy and natural resources [7], climate-change [8]; (ii) intervention problems such as sustainable manufacturing and engineering, restoration and remediation [9,10]; (iii) complementary tools such as Spatial/GIS [11], environmental impact assessment [5]; (iv) risk analysis and management [12] and others. Several authors serve as a reference source for describing the main MCDA tools useful to give answer to the different types of decision-making problems and the approaches taken to resolve them [4,13-21]. The most implemented, for example as synthetized by Guitoni, Martel et Vincke [19] and Ishizaka and Nemery [13], are:

1. ELimination Et Choix Traduisant la REalitè (ELECTRE) [22];

2. Multi-attribute utility theory (MAUT) [23];

3. Analytic Network Process (ANP) [24];

4. Measuring Attractiveness by a Categorical Based Evaluation (MACBETH) [25];

5. Analytic Hierarchy Process (AHP) [26];

6. Technique for Order of Preference by Similarity to Ideal Solution (TOPSIS) [27];

7. Preference Ranking Organization Method for Enrichment Evaluations (PROMETHEE) [28].

This synthesis is based on the contributions of, among others, Guitoni, Martel et Vincke (1999) [19], as well as of Roy et Bouysson (1993) [20], all of which were already attempts at taking a systematic approach to tools of MCDA.

In terms of settlement transformations, these tools can expand the bounds of fact-finding and decision-making exploration from mere consideration of the monetary criterion to the full range of relevant criteria (socio-economic, environmental, etc.).

But though the use of MCDA techniques is by now an established practice, there are no specific contributions to be found, either in Italy or the rest of Europe, on the procedures to be followed in selecting the MCDA tool best suited to the decision-making contexts of the settlement sector, and more specifically of the design and planning of public and private projects.

As a rule, the choice of the MCDA tool best suited to the objectives of the decision-making problem can significantly affect the consistency of the procedure with the stipulated objectives, as well as the proper formulation of the decisions to be made. It follows that the choices in question play a key role in arriving at a solution that provides a fully aware, optimal response to the needs and demands identified.

A synthesis of the various contributions cited above $[13,19,20]$ would include these points:

- no method (hereinafter 'tool') can be considered perfect or applied to every type of problem [13];

- the range of available procedures offers different operating opportunities, but also poses the risk of using tools not suited to the decision-making problem at hand [20];

- an axiomatic analysis of decision-making procedures has yet to be carried out [13].

In light of these considerations, the present work sets out to define a procedure which, in terms of the factors to be considered in addressing decision-making problems, makes it possible to select 
the MCDA tools best suited to problems of urban and settlement development, but which can also be employed in other decision-making contexts.

In the context of settlements, the proposed procedure can serve as a useful tool referring to the regulatory measures of the European Union governing public tenders, most recently Directive 2014/24/EU, transposed into Italian law by Legislative Decree No. 50/2016, plus subsequent modifications and additions.

This directive abrogated and updated Directive 2004/18/EC, which had been transposed into Italian law by Legislative Decree No. 163/2006, subsequently abrogated as well, though its measures of implementation, found in Presidential Decree No. 207/2010, are still in effect; these measures contemplate the use of MCDA in public tenders, particularly for the selection of the most economically advantageous bid. As early as 2006, for that matter, the European Commission had drawn up a manual with recommendations on systematic approaches to the use of MCDA in different fields of application [29].

In the present text: Section 2 provides an initial, theoretical-methodological analysis of MCDA, proposing a taxonomy of variables ('endogenous' and 'exogenous') to be considered in selecting the most appropriate tool from among those most widely found in the literature on problems of evaluation in processes of settlement transformation; Section 3 illustrates the procedure proposed for selecting MCDA tools; in Section 4 the proposed procedure is applied to a case study and the results of this application are discussed; Section 5 presents the conclusions of the present work.

\section{Multi-Criteria Decision Analysis (MCDA): Structure, Endogenous Variables, Exogenous Variables}

\subsection{Framework}

As a rule, any MCDA is structured in two macro-phases: the first involves the construction and compilation, with respect to the evaluation problem addressed, of the evaluation matrix, which consists of the different alternatives and their performance, based on the various criteria and sub-criteria (and their weightings), plus their indicators of assessment; the second regards the processing of the data of the evaluation matrix to evaluate the alternatives on the basis of the stipulated objectives [30,31].

The first macro-phase can be constructed in similar fashion for all MCDA tools [31]; in the second phase, on the other hand, the data can be processed (or aggregated) under a variety of different procedures, depending on which tool is used, seeing that each tool comes with its own procedures of implementation (referred to as the endogenous variables). It is customary, in selecting the tool best suited to meeting the objectives posed by the evaluation, to also take into account the context in which the evaluation occurs (referred to as the exogenous variables). Thus, the exogenous variables outline the 'external' context within which the MCDA is applied, and so they can vary, depending on the regulations and other measures that hold in the different countries in which evaluation processes occur.

This context gives rise to a number of decision-making problems tied to the phases of the settlement process. As shown by the literature on Life Cycle Management [32], the issues to be resolved during the different phases of the life cycle of a settlement process correspond to a variety of objectives [33].

In Italy, in terms of the national measures governing construction in general (Presidential Decree 380/2001, plus subsequent modifications and additions), and public contracts more specifically (Legislative Decree No. 50/2016, plus subsequent modifications and additions), categories can be established for the decision-making problems that arise in the different types of initiatives. The possible assessment queries can be classified on the basis of the phases around which the settlement process is structured, and for which, based on the objectives of evaluation, solutions are expected (Table 1). 
Table 1. Decision problem in Life Cycle Management related to settlement interventions.

\begin{tabular}{|c|c|c|c|c|}
\hline \multicolumn{2}{|c|}{ Phases of the Building Process } & Valuable Question & $\begin{array}{l}\text { Decision-Making } \\
\text { Problems }\end{array}$ & Decision Making Problems \\
\hline 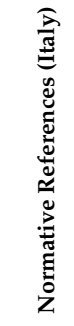 & $\begin{array}{l}\text { - Presidential } \\
\text { Decree 380/2001 } \\
\text { ss.mm.ii, } \\
\text { - Legislative Decree } \\
\text { 50/2016 ss.mm.ii }\end{array}$ & Legislative Decree 50/2016 ss.mm.ii & $\begin{array}{l}\text { - Law Decree 351/2001 } \\
\text { ss.mm.ii; } \\
\text { - Law Decree 112/2008 } \\
\text { ss.sm.ii; } \\
\text { - Legislative Decree } \\
\text { 42/2004 ss.mm.ii; } \\
\text { - Law Decree 85/2010 } \\
\text { ss.mm.ii }\end{array}$ & $\begin{array}{l}\text { Presidential Decree } \\
380 / 2001 \text { ss.mm.ii }\end{array}$ \\
\hline \multirow{3}{*}{ 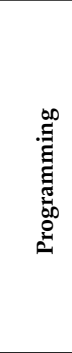 } & $\begin{array}{l}\text { Preliminary needs } \\
\text { studies }\end{array}$ & Priority of needs identification & \multirow{8}{*}{$\begin{array}{l}\text { - Settlement development; } \\
\text { - Redevelopment, recovery, } \\
\text { reuse, urban regeneration; } \\
\text { - Development of } \\
\text { discarded areas/buildings; } \\
\text { - Decision support in } \\
\text { project management; } \\
\text { - Valuation of public } \\
\text { buildings (Legislative } \\
\text { Decree 351/2001, Article } \\
\text { 3-bis of Legislative Decree } \\
\text { 112/2008, Article } 58 \text { of the } \\
\text { Italian Civil Code) } \\
\text { - Valorization of Cultural } \\
\text { Heritage (Law Decree. } \\
\text { 85/2010, Articles 5-7 } \\
\text { ss.mm.ii.) } \\
\text { - Valorization of } \\
\text { landscape-environmental } \\
\text { assets (Law Decree } \\
\text { 85/2010, Articles 5-7 } \\
\text { ss.mm.ii.) }\end{array}$} & \multirow{8}{*}{$\begin{array}{l}\text { - Restoration and } \\
\text { conservation interventions } \\
\text { (Art.3 (c); } \\
\text { - Renovation of buildings } \\
\text { (Article 3 (d); } \\
\text { - New construction works } \\
\text { (art.3, letter e1-e7); } \\
\text { - Urban planning } \\
\text { interventions (art.3, letter f) }\end{array}$} \\
\hline & $\begin{array}{l}\text { Designers and } \\
\text { advisors selection }\end{array}$ & $\begin{array}{l}\text { Identification of subjects to be } \\
\text { included in Lyfe Cycle Management }\end{array}$ & & \\
\hline & $\begin{array}{l}\text { Economic technical } \\
\text { feasibility project }\end{array}$ & $\begin{array}{l}\text { Design solution that identifies the } \\
\text { best relationship between cost and } \\
\text { benefit for the community, in relation } \\
\text { to the specific needs to be met and } \\
\text { performance to be provided } \\
\text { (Legislative Decree 50/2016, Article } \\
\text { 23, paragraph 5) }\end{array}$ & & \\
\hline \multirow[t]{2}{*}{ 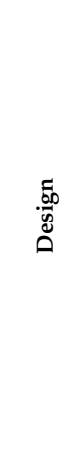 } & Definitive project & $\begin{array}{l}\text { Best design solution in accordance } \\
\text { with the requirements, criteria, } \\
\text { constraints, addresses and indications } \\
\text { set by the contracting authority and, } \\
\text { where applicable, the feasibility } \\
\text { project (Legislative Decree 50/2016, } \\
\text { Article 23, paragraph 7) }\end{array}$ & & \\
\hline & Executive project & $\begin{array}{l}\text { Best design solution in terms of form, } \\
\text { type, quality, size and price and in } \\
\text { relation to the solution proposed in } \\
\text { the maintenance plan of the work and } \\
\text { its parts in relation to the life cycle } \\
\text { (Legislative Decree 50/2016, art. 23, } \\
\text { co 8) }\end{array}$ & & \\
\hline 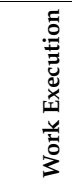 & Relocation of work & $\begin{array}{l}\text { Finding the best deal (based on the } \\
\text { most economically advantageous } \\
\text { bid criterion) }\end{array}$ & & \\
\hline \multirow{2}{*}{ 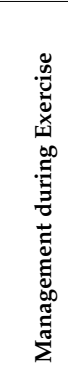 } & Service delivery & $\begin{array}{l}\text { Identify the most advantageous } \\
\text { management solution and/or the } \\
\text { most suitable operator in accordance } \\
\text { with the objectives }\end{array}$ & & \\
\hline & $\begin{array}{l}\text { Ordinary and } \\
\text { extraordinary } \\
\text { maintenance } \\
\text { (D.P.R.380/2001, } \\
\text { Article 3, par. 1, } \\
\text { letter a, b) }\end{array}$ & $\begin{array}{l}\text { Definition of the ordinary and } \\
\text { extraordinary maintenance solution } \\
\text { in relation to the modalities and times } \\
\text { for the interventions }\end{array}$ & & \\
\hline
\end{tabular}

Once the decision-making problem has been identified from among the possible assessment queries that can present themselves during the phases of a settlement transformation process, identification must also be made of the 'exogenous' variables (Section 2.2 and Table 2) of the MCDA tool found in the context in which the evaluation is implemented: (1) the number of evaluation elements (criteria and sub-criteria; alternatives); (2) the typology of indicators; (3) the number of stakeholders to be included in the decision process; (4) the typology of expected solutions; (5) whether or not the technical support of a Decision Aid Specialist is needed.

From a literature review it is easy to understand that there is not a single definition of the concept of MCDA and that many 'variables' can be traced out. Concisely, Roy [14] suggested that 
decision-making situations can be categorized on the base of decision problematics [15]; different kinds of compensation logics are examined by Vincke [16] and shared by Colson and De Bruyn [17] and other studies [18,34]; and Guitony et al. [19] and Huang et al. [5] looked at the required input information.

Considering scientific contributions and related summaries [4,13-21], a synthesis and a systematic framework is provided (Section 2.3 and Table 3), describing six variables, in the present work so-called endogenous, that characterize the different tools of MCDA, and so have an effect on the selection of the tool itself: (1) typology of the decision-making problem; (2) approaches of resolution; (3) data implementation procedures; (4) input levels; (5) typology of the output; (6) solution of the decision-making problem.

In addition to endogenous variables, in this work so-called exogenous variables have been defined as the ones strictly related to decision problems and the context from which the decision problem arises.

Each variable (exogenous or endogenous) presents qualifications that represent the various forms that the variable can take. Each tool possesses specific properties, in terms of its capacity for 'implementation', with these properties being tied to the qualifications of the variables.

In this work, the ensemble of exogenous and endogenous variables has been taken as a starting point on which to structure the selection procedure for the proposed MCDA method (see Section 3).

\subsection{Exogenous Variables}

In the present section exogenous variables are examined. Table 2 summarizes the features of the exogenous variables.

Table 2. Features of exogenous variables.

\begin{tabular}{|c|c|c|c|c|c|}
\hline $\begin{array}{l}\text { Number of Evaluation } \\
\text { Elements }\end{array}$ & $\begin{array}{l}\text { Typology of } \\
\text { Indicators }\end{array}$ & $\begin{array}{l}\text { Expected } \\
\text { Solution }\end{array}$ & $\begin{array}{l}\text { Technical Support } \\
\text { of a Decision Aid } \\
\text { Specialist }\end{array}$ & $\begin{array}{l}\text { Stakeholders to Be } \\
\text { Included in the } \\
\text { Decision Process }\end{array}$ & Tool \\
\hline $\begin{array}{l}\text { Limited number of criteria } \\
\text { and sub-criteria and a small } \\
\text { number of alternatives }\end{array}$ & \multirow{4}{*}{$\begin{array}{l}\text { - Quantitative; } \\
\text { - Qualitative; } \\
\text { - Mixed }\end{array}$} & $\begin{array}{l}\text { Definition of } n \\
\text { alternatives } \\
\text { valid in relation } \\
\text { to objectives }\end{array}$ & \multirow{4}{*}{$\begin{array}{l}\text { - Yes; } \\
\text { - No }\end{array}$} & \multirow{4}{*}{$\begin{array}{l}\text { - Participatory } \\
\text { process not activated; } \\
\text { - Participatory } \\
\text { process activated } \\
\text { with a limited and } \\
\text { specialized number } \\
\text { of stakeholder; } \\
\text { - Participatory } \\
\text { process activated } \\
\text { with a significant } \\
\text { number of } \\
\text { stakeholder } \\
\text { preferably organized } \\
\text { in categories }\end{array}$} & ELECTRE \\
\hline $\begin{array}{l}\text { Limited number of criteria } \\
\text { and sub-criteria and a large } \\
\text { number of alternatives }\end{array}$ & & \multirow{3}{*}{$\begin{array}{l}\text { A better overall } \\
\text { alternative } \\
\text { definition for } \\
\text { the purpose; } \\
\text { The ideal } \\
\text { alternative } \\
\text { definition } \\
\text { closest to } \\
\text { the lens }\end{array}$} & & & MAUT \\
\hline $\begin{array}{l}\text { Large number of criteria and } \\
\text { sub-criteria and a small } \\
\text { number of alternatives }\end{array}$ & & & & & $\mathrm{AHP} ; \mathrm{ANP}$ \\
\hline $\begin{array}{l}\text { Large number of criteria and } \\
\text { sub-criteria and a large } \\
\text { number of alternatives }\end{array}$ & & & & & $\begin{array}{l}\text { MACBETH; } \\
\text { PROMETHEE; } \\
\text { TOPSIS }\end{array}$ \\
\hline
\end{tabular}

\subsubsection{The Number of Evaluation Elements}

Depending on the different decision-making problems [5-8,11,12], the evaluation elements (criteria and sub-criteria, alternatives) can be configured: (i) as a limited number of criteria and sub-criteria and a limited number of alternatives; (ii) as a limited number of criteria and sub-criteria and an extensive number of alternatives; (iii) as an extensive number of criteria and sub-criteria and a limited number of alternatives; (iv) as an extensive number of criteria and sub-criteria and an extensive number of alternatives. The evaluation elements are generally defined by the process responsible for the evaluation before selecting the most suitable MCDA tool; in the case of settlement transformation processes, the number of criteria and sub-criteria is defined by the process manager (in Italy "responsabile del procedimento" Legislative Decree No. 50/2015 art. 31) since the definition of administrative acts for settlement process initiation. The number of criteria, sub-criteria and indicators may vary depending on the different evaluations that can be implemented; the person responsible for the evaluation process must be able to construct the set of evaluation elements without being influenced by the repercussions that the same set can create when selecting the MCDA tool. The set 
of criteria, sub-criteria and indicators must be significant in relation to the decision-making problem; the construction of the set must therefore meet the requirement of greater representativeness with the minimum number of possible elements [34-36]. The number of alternatives can be deduced taking into account what has happened in the past in similar settlement proceedings in the same or in other administrative contexts. It is then possible to know the number of criteria and sub-criteria and alternatives based on the evaluation problem to be solved.

\subsubsection{Typology of Indicators}

The typology of the indicators varies in accordance with the decision-making problem addressed and the context in which it arises. Indicators can be: (i) quantitative, or measurable in specific units of measure; (ii) qualitative, or not measurable in specific units of measure, but subject to judgments of merit that may also utilize specially designed scales of measurement (ordinal, cardinal or mixed); and (iii) mixed indicators that are both quantitative and qualitative.

\subsubsection{Stakeholders to be Included in the Decision Process}

The number of stakeholders involved in the decision-making process may vary depending on the different assessment questions that the MCDA has to give answer and also from the purpose of the decision-maker to activate a participatory process. The different models show several levels of appropriateness for the management of multiple points of view at the same time. It is therefore appropriate to consider whether, in the decision-making process: (i) participatory process (in the tables also P.P.) not activated; (ii) participatory process activated with a limited and specialized number of stakeholder; (iii) participatory process activated with a significant number of stakeholder, preferably organized in categories $[37,38]$. The involvement of stakeholders in the decision-making process is aimed at informing the decision-maker about the point of view of those who may be interested or influenced by the effects of the decision to be taken. The stakeholders to be included in the participatory process can be classified into [39]: (i) standard stakeholders "who have the legitimate responsibility to participate in the process" [39], including all those involved in the program's impacts (e.g., beneficiaries or those who have suffered damage), design engineers, public administration officials, etc. [29]; (ii) interest groups, stakeholders selected from local or professional representatives, leaders of non-governmental organizations (such as stakeholder or environmental protection, consumers, women's rights), public sector bodies, donors' representatives, etc. [29]. Concisely, interest groups are typically political parties, civic organizations, or residents of the impact area [39]. Each interest group - as well as standard stakeholder-has their own point of view for evaluating potential alternatives and often has different relational systems of preference. The process manager, in relation to his knowledge of the context in which the decision-making arises, identifies stakeholders to be included in the process. Depending on their interests, stakeholders will stand up for different alternatives and objectives, thus attributing weights expressing different interests and values [39]. Any possible divergence between stakeholders can be solved attributing them different importance through assigning a weight by the process manager (see Section 3.2). After attributing indices of importance to each stakeholder, the process manager can select the solution (MCDA tool) that is preferred for stakeholders, e.g., by a simple majority (solution which is preferred for stakeholders whose added indices of importance are greater than $50 \%$ ).

\subsubsection{Typology of the Expected Solution}

The typology of the expected solution for the decision-making problem examined depends on the type of information sought from the evaluation process. The expected solutions can be: (1) valid alternatives based on the objective; (2) the best alternative, based on the objective; (3) the alternative closest to the objective. 
2.2.5. Technical Support from a Decision Aid Specialist during the Implementation of the Procedure

Seeing that, as has been observed by the European Commission [29], the management of the multi-criteria evaluation process can prove anything but simple, another factor influencing the selection of the most suitable tool is the availability or not-availability of the support of a Decision Aid Specialist capable of operationally implementing the MCDA procedure.

The Decision Aid Specialist can play a dual role: both "technical" manager of the implementation of the MCDA tool identified to respond to the evaluation problem as well as "facilitator" for the decision-making phase(s) of the evaluation process understanding. In relation to the "technical" role, the Decision Aid Specialist deals with the implementation of the MCDA also by using the various software available. In literature, a wide variety of MCDA software is described, some of which available in commerce highlighting different kind of packages that have been developed to implement MCDA tools $[13,40,41]$. They use several processes of structuring decision-making problems including problem exploration, formulation, decomposition and solution [40] by using mathematics algorithms. Referring to the MCDA tools above mentioned (Section 1), literature review recommends some available, easy to use and free access or free trial version software: MakeItRational [41,42] or ExpertChoice [43] for AHP, SuperDecision [44] for ANP, RightChoice [45] for MAUT, M-MACBETH [46] for MACBETH, SmartPickerPro [47] for PROMETHEE, Electre III-IV software [48] for ELECTRE, Topsis [49] for TOPSIS. Some of this software is intuitive and easy to use because only decision problem structuring by data imputation (criteria, sub-criteria, alternatives, weights) is required from the person responsible of the evaluation process; the construction and solution of algorithms to solve decision problem and sensitivity analysis processing is provided by software. The software allows an automatic computation thanks also the user-friendly graphical interfaces and the support of open source and trial versions. e.g., in MakeItRational [42] software used for AHP implementation, "it is not necessary to know how priorities are calculated, only what should be ranked" [13] and "the correlation between the elements in the problem" [13]. This means that this kind of software generally do not allow to modify the algorithms structure in relation to the decision problem specificities. Transparence of outcomes and stakeholder acceptability is guaranteed by the decision problem structuring process. In this case the person responsible for the evaluation process can self-implement MCDA and rapidly obtain results. The low or no possibility to modify algorithms' structure may represent a drawback and/or a limitation on the coherence of outcomes in relation with evaluation aims. For example, in the software RightChoice [45], which supports the MAUT implementation, if the person responsible for the evaluation process uses exponential utility functions for several criteria, the exponents of those functions cannot be adapted for each criterion but they must be all the same [13]. Others software require to the person responsible for the evaluation process to completely or partially build the algorithms for: (i) decision problem structuring; (ii) decision problem solving; (iii) sensitivity analysis implementing. The Decision Aid Specialist as "technical" manager needs to have specific informatics programming and query languages knowledge to implement MCDA through this kind of software.

The Decision Aid Specialist as a "facilitator" has the task of making the MCDA's implementation steps clear to non-specialist stakeholders; thus, its presence also increases the level of transparency of the evaluation process for the decisions to be taken.

\subsection{Endogenous Variables}

In the present section endogenous variables are examined. Table 3 summarizes the features of the endogenous variables. 
Table 3. Features of endogenous variables.

\begin{tabular}{|c|c|c|c|c|c|c|}
\hline $\begin{array}{c}\text { Type of } \\
\text { Decision-Making } \\
\text { Problems }\end{array}$ & $\begin{array}{l}\text { Solution } \\
\text { Approach }\end{array}$ & $\begin{array}{l}\text { Implementation } \\
\text { Procedure }\end{array}$ & Input Level & Output Typology & $\begin{array}{c}\text { Decision } \\
\text { Problem Solution }\end{array}$ & Tool \\
\hline Sorting/Description & $\begin{array}{l}\text { Outranking } \\
\text { approach }\end{array}$ & $\begin{array}{l}\text { Preference } \\
\text { thresholds, } \\
\text { indifference } \\
\text { thresholds, veto } \\
\text { thresholds }\end{array}$ & Medium & $\begin{array}{l}\text { Partial ordering } \\
\text { obtained by } \\
\text { expressing } \\
\text { pairwise } \\
\text { preferences } \\
\text { degrees }\end{array}$ & $\begin{array}{l}n \text { categories of } \\
\text { alternatives of } \\
\text { equal score but } \\
\text { different } \\
\text { behaviour }\end{array}$ & ELECTRE \\
\hline \multirow{9}{*}{ Ranking/Choice } & \multirow{4}{*}{$\begin{array}{l}\text { Full } \\
\text { aggregation } \\
\text { approach }\end{array}$} & Utility function & High & $\begin{array}{l}\text { Full ordering } \\
\text { obtained by } \\
\text { considering the } \\
\text { scores }\end{array}$ & $\begin{array}{l}\text { Alternative with } \\
\text { the higher } \\
\text { global score }\end{array}$ & MAUT \\
\hline & & $\begin{array}{l}\text { Pairwise } \\
\text { comparison on } \\
\text { rational scale and } \\
\text { interdependencies }\end{array}$ & High & $\begin{array}{l}\text { Full ordering } \\
\text { obtained by } \\
\text { considering the } \\
\text { scores }\end{array}$ & $\begin{array}{l}\text { Alternative with } \\
\text { the higher } \\
\text { global score }\end{array}$ & ANP \\
\hline & & $\begin{array}{l}\text { Pairwise } \\
\text { comparison on } \\
\text { interval scale }\end{array}$ & High & $\begin{array}{l}\text { Full ordering } \\
\text { obtained by } \\
\text { considering the } \\
\text { scores }\end{array}$ & $\begin{array}{l}\text { Alternative with } \\
\text { the higher } \\
\text { global score }\end{array}$ & MACBETH \\
\hline & & $\begin{array}{l}\text { Pairwise } \\
\text { comparison on } \\
\text { rational scale }\end{array}$ & Low & $\begin{array}{l}\text { Full ordering } \\
\text { obtained by } \\
\text { considering the } \\
\text { scores }\end{array}$ & $\begin{array}{l}\text { Alternative with } \\
\text { the higher } \\
\text { global score }\end{array}$ & AHP \\
\hline & $\begin{array}{l}\text { Goal, } \\
\text { aspiration or } \\
\text { reference } \\
\text { level } \\
\text { approach }\end{array}$ & $\begin{array}{l}\text { Ideal option and } \\
\text { anti-ideal option }\end{array}$ & Low & $\begin{array}{l}\text { Full ordering with } \\
\text { score closest to the } \\
\text { aim assumed }\end{array}$ & $\begin{array}{l}\text { Alternative with } \\
\text { the closest score to } \\
\text { the ideal solution }\end{array}$ & TOPSIS \\
\hline & \multirow{4}{*}{$\begin{array}{l}\text { Outranking } \\
\text { approach }\end{array}$} & \multirow{2}{*}{$\begin{array}{l}\text { Preference } \\
\text { thresholds, } \\
\text { indifference } \\
\text { thresholds, veto } \\
\text { thresholds }\end{array}$} & \multirow{2}{*}{ Medium } & $\begin{array}{l}\text { Partial ordering } \\
\text { obtained by } \\
\text { expressing } \\
\text { pairwise } \\
\text { preferences } \\
\text { degrees }\end{array}$ & $\begin{array}{l}n \text { categories of } \\
\text { alternatives of } \\
\text { equal score but } \\
\text { different } \\
\text { behaviour }\end{array}$ & \multirow[t]{2}{*}{ ELECTRE } \\
\hline & & & & $\begin{array}{l}\text { Total ordering } \\
\text { obtained by } \\
\text { expressing } \\
\text { pairwise } \\
\text { preferences } \\
\text { degrees }\end{array}$ & $\begin{array}{l}\text { Alternative with } \\
\text { the higher } \\
\text { global score }\end{array}$ & \\
\hline & & \multirow[t]{2}{*}{$\begin{array}{l}\text { Preference } \\
\text { thresholds, } \\
\text { indifference } \\
\text { thresholds }\end{array}$} & \multirow{2}{*}{ Medium } & $\begin{array}{l}\text { Partial ordering } \\
\text { obtained by } \\
\text { expressing } \\
\text { pairwise } \\
\text { preferences } \\
\text { degrees }\end{array}$ & $\begin{array}{l}\mathrm{n} \text { categories of } \\
\text { alternatives of } \\
\text { equal score but } \\
\text { different } \\
\text { behaviour }\end{array}$ & \multirow{2}{*}{ PROMETHEE } \\
\hline & & & & $\begin{array}{l}\text { Partial ordering } \\
\text { obtained by } \\
\text { expressing } \\
\text { pairwise } \\
\text { preferences } \\
\text { degrees }\end{array}$ & $\begin{array}{l}\text { Alternative with } \\
\text { the higher } \\
\text { global score }\end{array}$ & \\
\hline
\end{tabular}

\subsubsection{Type of Decision-Making Problem}

Types of decision-making problem according to Roy's approach [20] shared, among others, by Ishizaka et Nemery P. [13] and Guitoni and Martel [15] can be grouped into three categories that express the qualification of the variable:

1. Description problem: the need to identify the main distinctive features for a group of alternatives;

2. Sorting problem: definition of homogeneous groups of alternatives by characteristics;

3. Ranking choice problem: ranking of alternatives, from best to worst. 


\subsubsection{Solution Approach}

The solving approach can be qualified in three clusters that are distinguished for the mode of resolution of the evaluation problem. The latter are:

1. Full aggregation approach: "A score is evaluated for each criterion and these are then synthesized into a global score. This approach assumes compensable scores, i.e., a bad score for one criterion is compensated for by a good score on another" [13]. These scores are expressed considering the performance set of the alternatives according to the criteria and sub-criteria selected for the implementation of the analysis. The scores allow to each alternative to be comparable with each other;

2. Outranking approach: "A bad score may not be compensated for by a better score. The order of the option may be partial because the notion of incomparability is allowed. Two options may have the same score, but their behavior may be different and therefore incomparable" [13]. The allocation of the full or partial score to the alternatives is based on the consideration of the performance set, based on the criteria and sub-criteria selected for the implementation of the analysis. The incomparability is defined by alternative performance sets equally valid but differently qualified because they are based on different sets of criteria;

3. Goal, aspiration or reference level approach: "This approach defines a goal on each criterion, and then identifies the closest options to the ideal goal or reference level" [13]. The options (alternatives) are evaluated through the aggregate collection (vector sum) of the performance in relation to the different criteria that allows to define the distances (vector) of alternatives from the objective assumed.

\subsubsection{Input Level}

The input level is connected to the measurement and qualification of the data and parameters to be traced and considered to solve the decision-making problem. This variable describes the "modeling effort" [13] needed to achieve the expected results and depends on: (i) data and parameters to be traced and input into the evaluation model (high, medium, low); (ii) requested time to collect and process data (long, medium, short); (iii) skills needed to manage and process data (high, medium, low); (iv) use of additional evaluation techniques (necessary, advised, unnecessary) for the collection of data to be used in the MCDA including Strategic Planning Techniques [50] and Participation Techniques. In the decision-making problem, several stakeholders can be considered directly or indirectly involved in the decision-making problem: institutions (national, regional, local), contracting stations, entrepreneurs, economic operators, property owners, workers, population [31].

The input level can be expressed through a synthetic indicator (Table 4) that represents the level: High (H), Medium (M), Low (L). To define the input level, a score is assigned to each of the four parameters considered in relation to the required modeling effort and by averaging the scores attributed to the four parameters considered. If the total score is less than 0.33 , the input level is low; if the total score is greater than 0.33 and not higher than 0.66 , the input level is average; if it is higher than 0.66 , the input level is high.

The implementation procedures of the collected (or defined) information result from the input data level.

Table 4. Weighing the modeling effort level in relation to the input level parameters.

\begin{tabular}{ccccc}
\hline \multirow{2}{*}{$\begin{array}{c}\text { Score to Be } \\
\text { Assigned }\end{array}$} & $\begin{array}{c}\text { Parameters for the Input Level Definition and Calculation } \\
\text { Quantity (i) }\end{array}$ & Definition Time (ii) & $\begin{array}{c}\text { Skills and Level of } \\
\text { Knowledge of the } \\
\text { Decision Problem (iii) }\end{array}$ & $\begin{array}{c}\text { Use of Other Integrated } \\
\text { Tecniques (iv) }\end{array}$ \\
\hline 1 & High & Long & High & Necessary \\
\hline 0.5 & Medium & Medium & Medium & Advised \\
\hline 0 & Low & Short & Low & Unnecessary \\
\hline
\end{tabular}




\subsubsection{Implementation Procedure}

The implementation procedures represent the logical-mathematical operations to process the data implemented in the evaluation matrix and to get summary results regarding the classification and qualification of the alternatives; for data-processing and data-aggregation the following procedures are used:

1. Preference thresholds, indifference thresholds, veto thresholds [51]: for obtaining a merit ranking of alternatives. Rank is constructed through the expression of pairwise preference degree when comparing the performance of $\mathrm{n}$ alternatives. For the expression of preference level, evaluation requires to consider the preference and indifference thresholds. On the basis of this thresholds positive, negative and net unicriterion and global flows are constructed taking into account the weights attributed to each criterion. If an action is negatively performing according to a single criterion, it may also be included a veto threshold that definitively excludes that option from the final ranking;

2. Utility function [21]: to express the measure of desirability or preference of each alternative respect the other. Different criteria are considered in the function; for each criteria, the marginal utility is determined representing the partial contribution that each criteria brings to the overall utility assessment [13]. Global utility is expressed by Global Utility Scores (generally expressed in values between 0 and 1) commonly calculated by the additive method or with a weighted sum, based on the weighted importance (weight) for each criterion, or a simple addition;

3. Pairwise comparisons on rational scale $[26,52]$ : through the construction of evaluation matrices. The comparison between the elements included in the evaluation matrices, structured according to a hierarchical system of Criteria, Sub-criteria and Alternatives, is performed by simultaneously comparing two elements at a time with respect to the hierarchically superior element on the basis of a rational numerical scale (Saaty Fundamental Scale);

4. Pairwise comparisons on rational scale with interdependencies [24]: through the construction of evaluation matrices called Supermatrix. Comparison of the elements included in the Supermatrix, organized into clusters of Criteria, Sub-Criteria and Alternatives, is performed by simultaneously comparing two elements at a time taking into account any interdependencies between them: (1) inner dependency in cluster criteria; (2) inner dependence in the alternative cluster; (3) outer dependency (correlation between two different clusters). Based on the influences (also called nodes) between elements or clusters, the Supermatrix is filled considering the influence of each node on each other is expressed on a rational scale (Saaty Fundamental Scale). In case there is no interdependence between the compared elements, the zero value is inserted into Supermatrix;

5. Pairwise comparisons on interval scale $[25,53]$ : through the construction of evaluation matrices also called matrices of judgments. The comparison between the elements of the evaluation (alternatives and criteria) is implemented by the pairwise comparison based on a semantic qualitative scale (traditionally translated into quantitative values from 1 to 7 ). Values are generally included in the matrix of judgments where the relative attractiveness of the criteria and alternatives is expressed also by the consideration of weight (attributed to each criterion);

6. Ideal option and anti-ideal option $[13,27,54-56]$ : expressing, for each alternative, the shortest distance to the ideal (virtual) solution and the longest distance from the anti-ideal solution, taking into account the performance of alternatives referred to each criterion and to the weight of each criterion. The distance is expressed by calculating a distributive normalization and an ideal normalization of recorded performances.

\subsubsection{Output Typology (Ordering of Alternatives)}

In relation to the implementation procedure used and to the input level of information to be considered, it is possible to obtain output or modalities of ordering alternatives of different quality. The "granularity order" $[13,19]$ varies according to the type of endogenous variables considered. 
The output types are obtained as a result of evaluation implementation referring to the number $n$ of evaluated alternatives. This depends on the comparability or incomparability between the alternatives themselves and the distance (or type of measurement or mechanics by which alternatives are ordered) of alternatives from the defined goal.

Outputs can take the following qualifications:

1. Partial and complete ordering obtained by expressing pairwise preference degrees and scores. This ordering is based on the simultaneous consideration of the positive and negative global performance flows evaluated for each alternative or on the sole consideration of the net flows that make it possible to understand whether the considered alternatives obtain a higher rank, a minor rank or if two or more alternatives are incomparable or equally valid;

2. Partial and complete ordering obtained by expressing pairwise outranking degrees. Preferred degrees can lead to a partial rank (if two or more alternatives are incomparable) or total rank (if the incomparability hypothesis is not allowed) of alternatives traditionally through the expression of degrees of concordance and discordance according to the criteria considered;

3. Full ordering obtained by considering the scores assigned to alternatives in several ways (pairwise comparisons with or without interdependencies, utility functions, pairwise comparisons on interval scale). These scores are complex and general (they do not accept hypotheses of incomparability between two alternatives) and generally allow the ordering of alternatives from the best to the worst;

4. Full order with score closest to the aim assumed. This is based on the calculation of the proximity coefficient for each alternative traditionally expressed in values between 0 and 1 where value 1 expresses the closest proximity to the aim.

\subsubsection{Decision Problem Solution}

The types of solution of the decision-making problem derive from the ordering (output) of the alternatives that can be referred to:

1. $\mathrm{n}$ categories of alternatives of equal score but different behavior. The hypothesis of incomparability between two alternatives is admitted and the solution to the decision-making problem is based on the consideration of several alternatives at the same time valid to make the choice;

2. Alternative with the higher global score: it does not admit the incomparability hypothesis between two alternatives and the decision-making solution is based on choosing the alternative that gets the highest score;

3. Alternative with the closest score to the ideal solution: it does not admit the hypothesis of incomparability between two alternatives and the solution to the decision problem is based on choosing the alternative that gets the closest score to the ideal normalization of the recorded performances for alternatives considered.

\subsection{Transposition of the Properties of MCDA Tools into a Binary Mathematical System}

The analyses carried out in Sections 2.2 and 2.3 above make it possible to construct a matrix that summarize the properties of the MCDA tools considered. This matrix consists of seven columns of the MCDA tools taken into consideration (Tn) and 38 rows of the qualifications (Qn) for each variable (Vn); at the intersection of each row and column, a binary mathematical system is used to transpose whether each of the properties of qualification is present (1) or absent (0) for a given variable $\mathrm{Px}(\mathrm{Tn} ; \mathrm{Vn} ; \mathrm{Qn})$ (Table 5). This transposition serves, in the following phase, for implementation of the procedure for selecting the MCDA tool best suited to the decision-making problem being addressed. 
Table 5. Property of multi-criteria decision analysis (MCDA) tools in binary mathematical system.

\begin{tabular}{|c|c|c|c|c|c|c|c|c|c|}
\hline \multirow{2}{*}{$\begin{array}{c}\text { Type of } \\
\text { Variables }\end{array}$} & \multirow{2}{*}{ Variables } & \multirow{2}{*}{ Qualification of Variables } & \multicolumn{7}{|c|}{ Properties of MCDA Tool in Binary System } \\
\hline & & & ELECTRE & MAUT & ANP & MACBETH & AHP & TOPSIS & PROMETHEE \\
\hline \multirow{16}{*}{ Exogenous } & \multirow{4}{*}{$\begin{array}{l}\text { Number of evaluation } \\
\text { elements }\end{array}$} & $\begin{array}{l}\text { Limited number of criteria and sub-criteria and } \\
\text { a small number of alternatives }\end{array}$ & 1 & 0 & 0 & 0 & 0 & 0 & 0 \\
\hline & & $\begin{array}{l}\text { Limited number of criteria and sub-criteria and } \\
\text { a large number of alternatives }\end{array}$ & 0 & 1 & 0 & 0 & 0 & 0 & 0 \\
\hline & & $\begin{array}{l}\text { Large number of criteria and sub-criteria and } \\
\text { a small number of alternatives }\end{array}$ & 0 & 0 & 1 & 0 & 1 & 0 & 0 \\
\hline & & $\begin{array}{l}\text { Large number of criteria and sub-criteria and } \\
\text { a large number of alternatives }\end{array}$ & 0 & 0 & 0 & 1 & 0 & 1 & 1 \\
\hline & \multirow{3}{*}{ Typology of indicators } & Quantitative & 1 & 1 & 1 & 1 & 1 & 1 & 1 \\
\hline & & Qualitative & 1 & 0 & 1 & 1 & 1 & 1 & 1 \\
\hline & & Mixed & 1 & 0 & 1 & 1 & 1 & 1 & 1 \\
\hline & \multirow{3}{*}{$\begin{array}{l}\text { Stakeholders to be } \\
\text { included in the } \\
\text { decision process }\end{array}$} & Participatory process not activated & 1 & 1 & 1 & 1 & 1 & 1 & 1 \\
\hline & & $\begin{array}{l}\text { Participatory process activated with a limited and } \\
\text { specialized number of stakeholder }\end{array}$ & 1 & 1 & 1 & 1 & 1 & 1 & 1 \\
\hline & & $\begin{array}{l}\text { Participatory process activated with a significant } \\
\text { number of stakeholder preferably organized in } \\
\text { categories }\end{array}$ & 1 & 1 & 1 & 1 & 1 & 1 & 1 \\
\hline & \multirow{4}{*}{ Expected solution } & $\begin{array}{l}\text { A better overall alternative definition for the } \\
\text { purpose }\end{array}$ & 1 & 0 & 0 & 0 & 0 & 0 & 0 \\
\hline & & The ideal alternative definition closest to the lens & 0 & 0 & 0 & 0 & 0 & 1 & 0 \\
\hline & & $\begin{array}{l}\text { A better overall alternative definition for the } \\
\text { purpose }\end{array}$ & 0 & 1 & 1 & 1 & 1 & 0 & 1 \\
\hline & & The ideal alternative definition closest to the lens & 0 & 0 & 0 & 0 & 0 & 1 & 0 \\
\hline & \multirow{2}{*}{$\begin{array}{l}\text { Technical support of a } \\
\text { Decision Aid Specialist }\end{array}$} & Yes (advisable) & 1 & 1 & 1 & 1 & 0 & 0 & 0 \\
\hline & & No (not necessary) & 0 & 0 & 0 & 0 & 1 & 1 & 1 \\
\hline \multirow{23}{*}{ Endogenous } & \multirow{3}{*}{$\begin{array}{l}\text { Type of decision-making } \\
\text { problems }\end{array}$} & Sorting & 1 & 0 & 0 & 0 & 0 & 0 & 0 \\
\hline & & Description & 1 & 0 & 0 & 0 & 0 & 0 & 0 \\
\hline & & Ranking/Choice & 1 & 1 & 1 & 1 & 1 & 1 & 1 \\
\hline & \multirow{3}{*}{ Solution approach } & Outranking approach & 1 & 0 & 0 & 0 & 0 & 0 & 1 \\
\hline & & Full aggregation approach & 0 & 1 & 1 & 1 & 1 & 0 & 0 \\
\hline & & Goal, aspiration or reference level approach & 0 & 0 & 0 & 0 & 0 & 1 & 0 \\
\hline & \multirow{7}{*}{$\begin{array}{l}\text { Implementation } \\
\text { procedure }\end{array}$} & $\begin{array}{l}\text { Preference thresholds, indifference thresholds, } \\
\text { veto thresholds }\end{array}$ & 1 & 0 & 0 & 0 & 0 & 0 & 0 \\
\hline & & Preference thresholds, indifference thresholds & 0 & 0 & 0 & 0 & 0 & 0 & 1 \\
\hline & & Utility function & 0 & 1 & 0 & 0 & 0 & 0 & 0 \\
\hline & & $\begin{array}{l}\text { Pairwise comparison on rational scale and } \\
\text { interdependencies }\end{array}$ & 0 & 0 & 1 & 0 & 0 & 0 & 0 \\
\hline & & Pairwise comparison on interval scale & 0 & 0 & 0 & 1 & 0 & 0 & 0 \\
\hline & & Pairwise comparison on rational scale & 0 & 0 & 0 & 0 & 1 & 0 & 0 \\
\hline & & Ideal option and anti-ideal option & 0 & 0 & 0 & 0 & 0 & 1 & 0 \\
\hline & \multirow{3}{*}{ Input level } & High & 0 & 1 & 1 & 1 & 1 & 0 & 0 \\
\hline & & Medium & 1 & 0 & 0 & 0 & 0 & 0 & 1 \\
\hline & & Low & 0 & 0 & 0 & 0 & 0 & 1 & 0 \\
\hline & \multirow{4}{*}{ Output typology } & $\begin{array}{l}\text { Partial ordering obtained by expressing pairwise } \\
\text { preferences degrees }\end{array}$ & 1 & 0 & 0 & 0 & 0 & 0 & 1 \\
\hline & & $\begin{array}{l}\text { Total ordering obtained by expressing pairwise } \\
\text { preferences degrees }\end{array}$ & 1 & 0 & 0 & 0 & 0 & 0 & 1 \\
\hline & & Full ordering obtained by considering the scores & 0 & 1 & 1 & 1 & 1 & 0 & 0 \\
\hline & & Full ordering with score closest to the aim assumed & 0 & 0 & 0 & 0 & 0 & 1 & 0 \\
\hline & \multirow{3}{*}{$\begin{array}{l}\text { Decision problem } \\
\text { solution }\end{array}$} & $\begin{array}{l}\mathrm{n} \text { categories of alternatives of equal score but } \\
\text { different behaviour }\end{array}$ & 1 & 0 & 0 & 0 & 0 & 0 & 1 \\
\hline & & Alternative with the higher global score & 0 & 1 & 1 & 1 & 1 & 0 & 0 \\
\hline & & $\begin{array}{l}\text { Alternative with the closest score to the } \\
\text { ideal solution }\end{array}$ & 0 & 0 & 0 & 0 & 0 & 1 & 0 \\
\hline
\end{tabular}

The transposition of the properties of MCDA tools into a binary mathematical system was elaborated on the basis of examining the most popular MCDA (see below Sections).

\section{The Procedure for Selecting Tools of Multi-Criteria Decision Analysis}

\subsection{Overview}

The selection of the most suitable MCDA tool can be carried out by comparing the framework of the properties that characterize each MCDA tool (Table 5) with the qualifications that the tool should present (expected properties), based on the decision-making problem to be addressed and taking into consideration both exogenous and endogenous variables. As was already shown in Section 1, the procedure is applicable to a variety of sectors, though reference shall be made below to settlement transformation; the procedure is structured as follows: 
1. Weighting of variables (optional action);

2. Determination of the framework of expected properties: identification (presence/absence) of the qualifications needed by the different variables to address the decision-making problem at hand;

3. Calculation of the overall index of suitability: based on a comparison of the properties of the MCDA tools (Table 3) with their expected properties, an overall index can be obtained for the suitability of each tool to the evaluation problem addressed;

4. Identification of the tool best suited to resolving the decision-making problem: ranking of the MCDA tools with respect to the overall suitability indicators obtained.

As already mentioned in the previous Sections, the proposed procedure was structured considering the six endogenous variables that characterize the different tools of MCDA derived from Ishizaka and Nemery's contribution [13], and four exogenous variables derived from the Italian regulatory framework inherent to the transformation processes settlements; the selection procedure of the most appropriate MCDA tool proposed below may be implemented in other territorial contexts and / or in other sectors of application: endogenous variables remain unchanged in the various possible applications as they are related to the implementation of MCDA "techniques"; exogenous variables can also be reconsidered by proceeding to a reduction/integration/substitution depending on the evaluation problem to be answered.

\subsection{Weighting of Variables (Optional Action)}

In reference with what has already been highlighted in the Section 3.1, a set of variables (that represent the criteria) with their possible qualifications (Table 5) has been defined. These will be used as a reference further in the text to illustrate the proposed procedure. The variables can be considered of equal importance/weights (equal weight method) or different importance/weight [57-59]. If must be considered the different importance of the variables, weight can be assigned to each variable [60]. Different weights influence directly the results of MCDA procedure. Consequently, it is necessary to obtain the rationality and veracity of criteria weights. The literature provides several methods to assess these weights: (i) subjective weighting methods: direct assignment, Simple Multi-Attribute Rating Technique (SMART), SWING, SIMOS, pair wise comparison, AHP; (ii) objective weighting methods: entropy method, TOPSIS, combination weighting methods [58,60-63].

It is possible to select the most appropriate weighting method taking into account the characteristics and the type of evaluation problem to be solved. Three factors are usually considered to obtain the weights: (i) the variance degree of criteria; (ii) the independency of criteria; (iii) the subjective preference of the decision-makers/stakeholders expressing their weights [60]. The number of criteria (and sub-criteria) may have relevance in order to select the most appropriate weighting method [34,51].

Direct assignment, SMART and SWING appear to be the most appropriate methods considering the proposed procedure features $[34,51,60]$ because: (i) variables considered are different and independent from each other and in limited number; (ii) different stakeholders (standard and interest group considered as categories) can express their point of view. These three methods have among its strengths the fast implementation times and the possibility to collect the point of view of stakeholders through questionnaires; among its weaknesses must be considered the difficulties connected to quantifying uncertain in human input [58] and the subsequent match between thoughts and priorities of stakeholders and the expression of ranking and values. In their implementation, and particularly with direct assignment, the presence of a Decision Aid Specialist may help to limit the weaknesses of this method by supporting the one who weights in extending its priorities for a balanced allocation of weights.

In the case study in the following Section 4, the equal method has been proposed; in case of weighting necessity, direct assignment can be used for the capability to directly assign weight without any mathematical normalization, making weighting operation faster. Direct assignment can be implemented attributing, for each variable, an index of importance $\mathrm{W}(\mathrm{Vn})$ between 0 (zero importance) 
and 1 (very high importance). This operation, which is optional for the implementation of the procedure, can be carried out by the person responsible for the evaluation process, or taking into account the opinion expressed by other stakeholders involved in the process on the invitation of the person responsible the same.

If the person responsible for the evaluation process opts for the weighting of the variables by stakeholders grouped into categories, the index of importance (for each variable) for each category must be determined. The different indices of importance, distinct for each variable, can be aggregated by averaging them:

- $\quad$ simple if all stakeholders are considered of equal importance;

- $\quad$ weighted if the stakeholders are considered of different importance [64].

For selecting the most suitable MCDA tool, the process manager can select the solution which is preferred for stakeholders whose added indices of importance is greater than a specified threshold (related to simple/relative/qualified majority, unanimity). The process manager can set the threshold in relation to the different composition of the stakeholders considered (increasing threshold as the number of stakeholders' points of view increases).

\subsection{Determination of the Framework of Expected Properties}

The subject responsible for the process of settlement transformation for which a decision-making problem needs to be resolved must indicate the needs and demands arising from the decision-making problem in question. Based on the various exogenous and endogenous variables, identification must be made of both the required and expected properties $\mathrm{EP}(\mathrm{Vn} ; \mathrm{Qn})$ of the tool to be used to respond to the decision-making problem.

The framework of the expected properties (for the tool to be used) (Table 6) is determined by deciding whether, for a given variable, each qualification is required or not (1) and (2):

$$
\begin{gathered}
\text { if } \mathrm{EP}(\mathrm{Vn} ; \mathrm{Qn})=\text { request } \mathrm{EP}(\mathrm{Vn} ; \mathrm{Qn})=\text { yes }(1) \\
\text { if } \mathrm{EP}(\mathrm{Vn} ; \mathrm{Qn})=\text { not request } \quad \mathrm{EP}(\mathrm{Vn} ; \mathrm{Qn})=\text { no }(0)
\end{gathered}
$$

\subsection{Calculation of the Overall Index of Suitability}

Before an overall index of suitability can be calculated, a suitability result SR(Vn; Qn) must be arrived at for each qualification of the variables that are to be listed on a new table. The suitability results are determined by comparing, for each qualification of the variable, the data on the properties of the MCDA tools (Table 3) with the data entered on the table of expected properties (Table 5). The comparison can generate 4 possible configurations (3)-(6):

$$
\begin{array}{ll}
\text { If } \mathrm{P}(\mathrm{Tn} ; \mathrm{Vn} ; \mathrm{Qn})=1 ; \mathrm{EP}(\mathrm{Vn} ; \mathrm{Qn})=1 & \mathrm{SR}(\mathrm{Vn} ; \mathrm{Qn})=1 \\
\text { if } \mathrm{P}(\mathrm{Tn} ; \mathrm{Vn} ; \mathrm{Qn})=1 ; \mathrm{EP}(\mathrm{Vn} ; \mathrm{Qn})=0 & \mathrm{SR}(\mathrm{Vn} ; \mathrm{Qn})=0 \\
\text { if } \mathrm{P}(\mathrm{Tn} ; \mathrm{Vn} ; \mathrm{Qn})=0 ; \mathrm{EP}(\mathrm{Vn} ; \mathrm{Qn})=1 & \mathrm{SR}(\mathrm{Vn} ; \mathrm{Qn})=0 \\
\text { if } \mathrm{P}(\mathrm{Tn} ; \mathrm{Vn} ; \mathrm{Qn})=0 ; \mathrm{EP}(\mathrm{Vn} ; \mathrm{Qn})=0 & \mathrm{SR}(\mathrm{Vn} ; \mathrm{Qn})=0
\end{array}
$$

The suitability results $\mathrm{SR}(\mathrm{Vn} ; \mathrm{Qn})$ for each variable are then combined for each MCDA tool to produce an aggregate index of suitability IS(Tn).

If it is chosen to weigh the variables, the suitability results must be multiplied by the importance index expressed by the stakeholders in order to obtain suitability results weighted through the equation:

$$
\mathrm{SRW}=\mathrm{SR}(\mathrm{Vn} ; \mathrm{Qn}) * \mathrm{~W}(\mathrm{Vn})
$$

where: 
$\mathrm{SRW}(\mathrm{Vn} ; \mathrm{Qn})$ : suitability results (partial coherence results) weighted;

$\mathrm{SR}(\mathrm{Vn} ; \mathrm{Qn})$ : suitability results (partial coherence results);

$\mathrm{W}(\mathrm{Vn})$ : weighting judgement expressed on Vn variable (between 0 and 1).

In the event that, for a single variable, the suitability of two or more qualifications has been determined, then the condition that holds for calculating overall suitability is that, when the binary system produces a number of suitability results that are equal to 1 , the overall result is 1 .

If it is not chosen to weigh the variables, the aggregate index of overall suitability IS(Tn) for each MCDA index is arrived with the equation:

$$
\mathrm{IS}(\mathrm{Tn})=\frac{\sum_{\mathrm{k}=0}^{\mathrm{n}} \mathrm{SR}(\mathrm{Vn} ; \mathrm{Qn})}{\mathrm{NVn}}
$$

where:

IS(Tn): index of overall suitability (overall coherence index);

$\mathrm{SR}(\mathrm{Vn} ; \mathrm{Qn})$ : suitability results (partial coherence results);

NVn: number of variables considered.

If it is chosen to weigh the variables, the aggregate index of overall suitability weighted ISW(Tn) for each MCDA index is arrived with the equation:

$$
\operatorname{ISW}(\mathrm{Tn})=\frac{\sum_{\mathrm{k}=0}^{\mathrm{n}} \mathrm{SRW}(\mathrm{Vn} ; \mathrm{Qn})}{\mathrm{NVn}}
$$

where:

ISW(Tn): index of overall suitability (overall coherence index) weighted;

$\mathrm{SRW}(\mathrm{Vn} ; \mathrm{Qn})$ : suitability results (partial coherence results) weighted;

NVn: number of variables considered.

\begin{tabular}{|c|c|c|c|c|}
\hline Type of Variables & Weight & Variables & Qualification of Variables & $\begin{array}{l}\text { Expected Properties in Relation to } \\
\text { Decision-Making Problem }\end{array}$ \\
\hline \multirow{15}{*}{ Exogenous } & \multirow{4}{*}{$0 \leq \mathrm{W} \leq 1$} & \multirow{4}{*}{$\begin{array}{l}\text { Number of } \\
\text { evaluation } \\
\text { elements }\end{array}$} & $\begin{array}{l}\text { Limited number of criteria and } \\
\text { sub-criteria and a small number of } \\
\text { alternatives }\end{array}$ & Request $=1 ;$ Not request $=0$ \\
\hline & & & $\begin{array}{l}\text { Limited number of criteria and } \\
\text { sub-criteria and a large number of } \\
\text { alternatives }\end{array}$ & Request $=1 ;$ Not request $=0$ \\
\hline & & & $\begin{array}{l}\text { Large number of criteria and sub-criteria } \\
\text { and a small number of alternatives }\end{array}$ & Request $=1 ;$ Not request $=0$ \\
\hline & & & $\begin{array}{l}\text { Large number of criteria and sub-criteria } \\
\text { and a large number of alternatives }\end{array}$ & Request $=1 ;$ Not request $=0$ \\
\hline & \multirow{3}{*}{$0 \leq \mathrm{W} \leq 1$} & \multirow{3}{*}{$\begin{array}{l}\text { Typology of } \\
\text { indicators }\end{array}$} & Quantitative & Request $=1 ;$ Not request $=0$ \\
\hline & & & Qualitative & Request $=1 ;$ Not request $=0$ \\
\hline & & & Mixed & Request $=1 ;$ Not request $=0$ \\
\hline & \multirow{3}{*}{$0 \leq \mathrm{W} \leq 1$} & \multirow{3}{*}{$\begin{array}{l}\text { Stakeholders to be } \\
\text { included in the } \\
\text { decision process }\end{array}$} & Participatory process not activated & Request $=1 ;$ Not request $=0$ \\
\hline & & & $\begin{array}{l}\text { Participatory process activated with a } \\
\text { limited and specialized number of } \\
\text { stakeholder }\end{array}$ & Request $=1 ;$ Not request $=0$ \\
\hline & & & $\begin{array}{l}\text { Participatory process activated with a } \\
\text { significant number of stakeholder } \\
\text { preferably organized in categories }\end{array}$ & Request $=1 ;$ Not request $=0$ \\
\hline & \multirow{3}{*}{$0 \leq \mathrm{W} \leq 1$} & \multirow{3}{*}{ Expected solution } & $\begin{array}{l}\text { Definition of } n \text { alternatives valid in } \\
\text { relation to objectives }\end{array}$ & Request $=1 ;$ Not request $=0$ \\
\hline & & & $\begin{array}{l}\text { A better overall alternative definition for } \\
\text { the purpose }\end{array}$ & Request $=1 ;$ Not request $=0$ \\
\hline & & & $\begin{array}{l}\text { The ideal alternative definition closest to } \\
\text { the lens }\end{array}$ & Request $=1 ;$ Not request $=0$ \\
\hline & \multirow{2}{*}{$0 \leq \mathrm{W} \leq 1$} & \multirow{2}{*}{$\begin{array}{l}\text { Technical support } \\
\text { of a Decision Aid } \\
\text { Specialist }\end{array}$} & Yes (advisable) & Request $=1 ;$ Not request $=0$ \\
\hline & & & No (not necessary) & Request $=1 ;$ Not request $=0$ \\
\hline
\end{tabular}

Table 6. Table to be filled out to define the set of expected properties. 
Table 6. Cont.

\begin{tabular}{|c|c|c|c|c|}
\hline Type of Variables & Weight & Variables & Qualification of Variables & $\begin{array}{l}\text { Expected Properties in Relation to } \\
\text { Decision-Making Problem }\end{array}$ \\
\hline \multirow{23}{*}{ Endogenous } & \multirow{3}{*}{$0 \leq W \leq 1$} & \multirow{3}{*}{$\begin{array}{l}\text { Type of } \\
\text { decision-making } \\
\text { problems }\end{array}$} & Sorting & Request $=1 ;$ Not request $=0$ \\
\hline & & & Description & Request $=1 ;$ Not request $=0$ \\
\hline & & & Ranking/Choice & Request $=1 ;$ Not request $=0$ \\
\hline & \multirow{3}{*}{$0 \leq \mathrm{W} \leq 1$} & \multirow{3}{*}{ Solution approach } & Outranking approach & Request $=1 ;$ Not request $=0$ \\
\hline & & & Full aggregation approach & Request $=1 ;$ Not request $=0$ \\
\hline & & & $\begin{array}{l}\text { Goal, aspiration or reference level } \\
\text { approach }\end{array}$ & Request $=1 ;$ Not request $=0$ \\
\hline & \multirow{7}{*}{$0 \leq W \leq 1$} & \multirow{7}{*}{$\begin{array}{l}\text { Implementation } \\
\text { procedure }\end{array}$} & $\begin{array}{l}\text { Preference thresholds, indifference } \\
\text { thresholds, veto thresholds }\end{array}$ & Request $=1 ;$ Not request $=0$ \\
\hline & & & $\begin{array}{l}\text { Preference thresholds, indifference } \\
\text { thresholds }\end{array}$ & Request $=1 ;$ Not request $=0$ \\
\hline & & & Utility function & Request $=1 ;$ Not request $=0$ \\
\hline & & & $\begin{array}{l}\text { Pairwise comparison on rational scale } \\
\text { and interdependencies }\end{array}$ & Request $=1 ;$ Not request $=0$ \\
\hline & & & Pairwise comparison on interval scale & Request $=1 ;$ Not request $=0$ \\
\hline & & & Pairwise comparison on rational scale & Request $=1 ;$ Not request $=0$ \\
\hline & & & Ideal option and anti-ideal option & Request $=1 ;$ Not request $=0$ \\
\hline & \multirow{3}{*}{$0 \leq \mathrm{W} \leq 1$} & \multirow{3}{*}{ Input level } & High & Request $=1 ;$ Not request $=0$ \\
\hline & & & Medium & Request $=1 ;$ Not request $=0$ \\
\hline & & & Low & Request $=1 ;$ Not request $=0$ \\
\hline & \multirow{4}{*}{$0 \leq \mathrm{W} \leq 1$} & \multirow{4}{*}{ Output typology } & $\begin{array}{l}\text { Partial ordering obtained by expressing } \\
\text { pairwise preferences degrees }\end{array}$ & Request $=1$; Not request $=0$ \\
\hline & & & $\begin{array}{l}\text { Total ordering obtained by expressing } \\
\text { pairwise preferences degrees }\end{array}$ & Request $=1 ;$ Not request $=0$ \\
\hline & & & $\begin{array}{l}\text { Full ordering obtained by considering the } \\
\text { scores }\end{array}$ & Request $=1 ;$ Not request $=0$ \\
\hline & & & $\begin{array}{l}\text { Full ordering with score closest to the aim } \\
\text { assumed }\end{array}$ & Request $=1 ;$ Not request $=0$ \\
\hline & \multirow{3}{*}{$0 \leq \mathrm{W} \leq 1$} & \multirow{3}{*}{$\begin{array}{l}\text { Decision problem } \\
\text { solution }\end{array}$} & $\begin{array}{l}\mathrm{n} \text { categories of alternatives of equal score } \\
\text { but different behaviour }\end{array}$ & Request $=1 ;$ Not request $=0$ \\
\hline & & & Alternative with the higher global score & Request $=1 ;$ Not request $=0$ \\
\hline & & & $\begin{array}{l}\text { Alternative with the closest score to the } \\
\text { ideal solution }\end{array}$ & Request $=1 ;$ Not request $=0$ \\
\hline
\end{tabular}

\subsection{Ranking and Selection of MCDA Tools}

The ranking, POS(Sn), of the overall indexes of suitability for each MCDA tool is carried out by listing the indexes of aggregate suitability, IS(Tn) or ISW(Tn), in descending order. The most suitable tool is the one with the highest index of overall suitability.

\section{Case Study and Results}

4.1. Procedure Application for Selecting the MCDA Instrument to Evaluate Design Proposals in the Call for Tenders for a New Office Building of the Chamber of Deputies in Rome

The procedure was applied assuming the need to select the MCDA instrument to be indicated in the international call for tenders to get design ideas for a new office building of the Chamber of Deputies in Rome. The new building is to be realized in an urban void adjacent to the Palace of Montecitorio in the historic center of Rome. The hypothetical call aims at identifying the best design idea for the solution of a fabric fracture unsolved since the call for tenders for the office building of the Chamber of Deputies of 1967.

The purpose of the call is to choose among multiple design proposals the best one considering their performances based on a set of criteria, sub-criteria and indicators specifically designed by a team of experts (Table 7) $[9,10]$. In the case study, the procedure was applied without weighing the variables. 
Table 7. Goal, objectives, criteria, sub-criteria and indicators of the call for tenders for the office building of the Chamber of Deputies.

\begin{tabular}{|c|c|c|c|c|c|}
\hline Goal & $\begin{array}{c}\text { General } \\
\text { Objectives }\end{array}$ & Criteria & Sub-Criteria & & ators \\
\hline \multirow{12}{*}{$\begin{array}{l}\text { The urban void } \\
\text { solution by the } \\
\text { inclusion of } \\
\text { new functions }\end{array}$} & \multirow{5}{*}{$\begin{array}{l}\text { Architectural } \\
\text { and Urban } \\
\text { quality }\end{array}$} & \multirow{2}{*}{$\begin{array}{l}\text { Urban fabric } \\
\text { filling in } \\
\text { relashionship } \\
\text { with the } \\
\text { historical } \\
\text { development } \\
\text { process }\end{array}$} & $\begin{array}{l}\text { Alignement of the new } \\
\text { building to the urban } \\
\text { fabrics before demolition } \\
\text { (Rilievo IGM 1873) }\end{array}$ & Qualitative & $\begin{array}{l}\text { - Total; } \\
\text { - Partial; } \\
\text { - Absent }\end{array}$ \\
\hline & & & $\begin{array}{l}\text { Presence of inner courts } \\
\text { (covered or uncovered) } \\
\text { following the tradition of } \\
\text { the historical urban fabric }\end{array}$ & Qualitative & $\begin{array}{l}\text { - Presemt; } \\
\text { - Absent }\end{array}$ \\
\hline & & \multirow{3}{*}{$\begin{array}{l}\text { Organic } \\
\text { relashionship } \\
\text { between } \\
\text { buildings and } \\
\text { urban spaces }\end{array}$} & $\begin{array}{l}\text { Connection between } \\
\text { design spaces, urban } \\
\text { spaces and parliamentary } \\
\text { functions close to the } \\
\text { design area }\end{array}$ & Qualitative & $\begin{array}{l}\text { - Very high; } \\
\text { - High; } \\
\text { - Meidum; } \\
\text { - Low; } \\
\text { - Very low }\end{array}$ \\
\hline & & & $\begin{array}{l}\text { Mixed use providing by } \\
\text { concentration of } \\
\text { commercial functions on } \\
\text { Matrix route in order to } \\
\text { restore its functional and } \\
\text { morphological continuity }\end{array}$ & Qualitative & $\begin{array}{l}\text { - Total; } \\
\text { - Partial; } \\
\text { - Absent }\end{array}$ \\
\hline & & & $\begin{array}{l}\text { Easy access to non } \\
\text { parliamentary functions } \\
\text { on matrix route (Via di } \\
\text { Campo Marzio) }\end{array}$ & Qualitative & $\begin{array}{l}\text { - Total; } \\
\text { - Partial; } \\
\text { - Absent }\end{array}$ \\
\hline & \multirow{2}{*}{$\begin{array}{l}\text { Technical and } \\
\text { functional } \\
\text { quality }\end{array}$} & \multirow{2}{*}{$\begin{array}{l}\text { Flexibility and } \\
\text { integrability of } \\
\text { inner and outer } \\
\text { spaces from } \\
\text { functional and } \\
\text { distributive } \\
\text { point of view }\end{array}$} & $\begin{array}{l}\text { Minimizing of unmovable } \\
\text { structures to reduce the } \\
\text { impact on the dinamic and } \\
\text { alternative use of spaces }\end{array}$ & Qualitative & $\begin{array}{l}\text { - Very high; } \\
\text { - High; } \\
\text { - Meidum; } \\
\text { - Low; } \\
\text { - Very low }\end{array}$ \\
\hline & & & $\begin{array}{l}\text { Minimizing of tecnical and } \\
\text { structural elements to } \\
\text { reduce the impact on the } \\
\text { dynamic and alternative } \\
\text { use of spaces }\end{array}$ & Qualitative & $\begin{array}{l}\text { - Total; } \\
\text { - Partial; } \\
\text { - Absent }\end{array}$ \\
\hline & \multirow{5}{*}{$\begin{array}{l}\text { Economic and } \\
\text { finalncial } \\
\text { aspects }\end{array}$} & \multirow{3}{*}{$\begin{array}{l}\text { Spending } \\
\text { Control }\end{array}$} & Cost reduction & Quantitative & $\begin{array}{l}\% \text { on base } \\
\text { amount } \\
\text { established for } \\
\text { call for tenders }\end{array}$ \\
\hline & & & $\begin{array}{l}\text { Cost sustainability } \\
\text { connected with energy } \\
\text { saving }\end{array}$ & Quantitative & $€ /$ year \\
\hline & & & $\begin{array}{l}\text { Maintenance costs } \\
\text { por year }\end{array}$ & Quantitative & $€ /$ year \\
\hline & & \multirow{2}{*}{$\begin{array}{l}\text { Economic } \\
\text { Convinience }\end{array}$} & Environmental costs & Quantitative & $€$ \\
\hline & & & Costs Benefits ratio & Quantitative & $\begin{array}{l}\text { Net Present } \\
\text { Value }(€)\end{array}$ \\
\hline
\end{tabular}

\subsection{Definition of Expected Properties}

The expected properties of the MCDA tool used to evaluate the design proposals (Table 8) have been taken into account considering the objectives and the peculiarities that characterize the call itself. 
Table 8. Definition of expected properties for the MCDA Tool in the call for tenders for the office building of the Chamber of Deputies in Rome.

\begin{tabular}{|c|c|c|c|c|}
\hline Type of Variables & Variables & Qualification of Variables & $\begin{array}{l}\text { Expected Properties } \\
\text { to Decision Making } \\
\text { Problem }\end{array}$ & Related to: \\
\hline \multirow{15}{*}{ Exogenous } & \multirow{4}{*}{$\begin{array}{l}\text { Number of } \\
\text { evaluation elements }\end{array}$} & $\begin{array}{l}\text { Limited number of criteria and sub-criteria and a small } \\
\text { number of alternatives }\end{array}$ & 0 & - \\
\hline & & $\begin{array}{l}\text { Limited number of criteria and sub-criteria and a large } \\
\text { number of alternatives }\end{array}$ & 0 & - \\
\hline & & $\begin{array}{l}\text { Large number of criteria and sub-criteria and a small number } \\
\text { of alternatives }\end{array}$ & 0 & - \\
\hline & & $\begin{array}{l}\text { Large number of criteria and sub-criteria and a large number } \\
\text { of alternatives }\end{array}$ & 1 & $\begin{array}{l}\text { Criteria, Sub-Criteria and Indicators } \\
\text { of Evaluation; Considering a } \\
\text { significant participation in the call }\end{array}$ \\
\hline & \multirow{3}{*}{$\begin{array}{l}\text { Typology of } \\
\text { indicators }\end{array}$} & Quantitative & 0 & - \\
\hline & & Qualitative & 0 & - \\
\hline & & Mixed & 1 & $\begin{array}{l}\text { Criteria, Sub-Criteria and Indicators } \\
\text { of Evaluation }\end{array}$ \\
\hline & \multirow{3}{*}{$\begin{array}{l}\text { Stakeholders to be } \\
\text { included in the } \\
\text { decision process }\end{array}$} & P.P. not activated & 0 & \\
\hline & & $\begin{array}{l}\text { P.P. activated with a limited and specialized number of } \\
\text { stakeholder }\end{array}$ & 0 & \\
\hline & & $\begin{array}{l}\text { P.P. activated with a significant number of stakeholder } \\
\text { preferably organized in categories }\end{array}$ & 1 & $\begin{array}{l}\text { Need to activate a participatory } \\
\text { process with a significant number of } \\
\text { categories of stakeholders }\end{array}$ \\
\hline & \multirow{3}{*}{ Expected solution } & Definition of $n$ alternatives valid in relation to objectives & 0 & - \\
\hline & & A better overall alternative definition for the purpose & 1 & $\begin{array}{l}\text { Need to select the best design } \\
\text { proposal }\end{array}$ \\
\hline & & The ideal alternative definition closest to the lens & 0 & - \\
\hline & \multirow{2}{*}{$\begin{array}{l}\text { Technical support of a } \\
\text { Decision Aid } \\
\text { Specialist }\end{array}$} & Yes (advisable) & 1 & Need to speed up decision making \\
\hline & & No (not necessary) & 0 & - \\
\hline \multirow{23}{*}{ Endogenous } & \multirow{3}{*}{$\begin{array}{l}\text { Type of decision } \\
\text { making problems }\end{array}$} & Sorting & 0 & - \\
\hline & & Description & 0 & - \\
\hline & & Ranking/Choice & 1 & $\begin{array}{l}\text { Need to form a ranking among the } \\
\text { design proposals }\end{array}$ \\
\hline & \multirow{3}{*}{ Solution approach } & Outranking approach & 0 & - \\
\hline & & Full aggregation approach & 1 & \multirow{2}{*}{$\begin{array}{l}\text { Necessity of project proposals in } \\
\text { relation to all achievements }\end{array}$} \\
\hline & & Goal, aspiration or reference level approach & 1 & \\
\hline & \multirow{7}{*}{$\begin{array}{l}\text { Implementation } \\
\text { procedure }\end{array}$} & $\begin{array}{l}\text { Preference thresholds, indifference thresholds, } \\
\text { veto thresholds }\end{array}$ & 0 & - \\
\hline & & Preference thresholds, indifference thresholds & 1 & $\begin{array}{l}\text { Need to check the performance of } \\
\text { project proposals in relation to } \\
\text { thresholds }\end{array}$ \\
\hline & & Utility function & 0 & - \\
\hline & & Pairwise comparison on rational scale and interdependencies & 0 & - \\
\hline & & Pairwise comparison on interval scale & 0 & - \\
\hline & & Pairwise comparison on rational scale & 0 & - \\
\hline & & Ideal option and anti-ideal option & 1 & $\begin{array}{l}\text { Need to check the performance of } \\
\text { project proposals in relation } \\
\text { to thresholds }\end{array}$ \\
\hline & \multirow[t]{3}{*}{ Input level } & High & 1 & $\begin{array}{l}\text { Calculation Table 4: amount of data } \\
\text { and parameters: high; Times for the } \\
\text { definition: medium; Skills and } \\
\text { degree of knowledge of the } \\
\text { decision-making problem: high; Use } \\
\text { of integrated techniques: } \\
\text { not necessary }\end{array}$ \\
\hline & & Medium & 0 & - \\
\hline & & Low & 0 & - \\
\hline & \multirow{4}{*}{ Output typology } & $\begin{array}{l}\text { Partial ordering obtained by expressing pairwise preferences } \\
\text { degrees }\end{array}$ & 0 & - \\
\hline & & $\begin{array}{l}\text { Total ordering obtained by expressing pairwise preferences } \\
\text { degrees }\end{array}$ & 0 & - \\
\hline & & Full ordering obtained by considering the scores & 1 & \multirow{2}{*}{$\begin{array}{l}\text { Need to measure the performance of } \\
\text { project proposals }\end{array}$} \\
\hline & & Full ordering with score closest to the aim assumed & 1 & \\
\hline & \multirow{3}{*}{$\begin{array}{l}\text { Decision problem } \\
\text { solution }\end{array}$} & $\begin{array}{l}\mathrm{n} \text { categories of alternatives of equal score but } \\
\text { different behaviour }\end{array}$ & 0 & - \\
\hline & & Alternative with the higher global score & 1 & \multirow{2}{*}{$\begin{array}{l}\text { Need to identify the project proposal } \\
\text { with the best performance in } \\
\text { relation to the goals }\end{array}$} \\
\hline & & Alternative with the closest score to the ideal solution & 1 & \\
\hline
\end{tabular}

\subsection{Calculation of Synthetic Coherence Indicator}

According to the procedure, the comparison between the property framework of MCDA tools (Table 3) and the list of expected properties (Table 8) provides the results of consistency for each qualification of the variables. Their aggregation allows to obtain the synthetic global coherence indicator IS(Tn) relative to each of the most commonly used MCDA tools (Table 9). 
Table 9. Consistency results of MCDA tools potentially usable in selecting the best design proposal in the call for tenders for the office building of the Chamber of Deputies.

\begin{tabular}{|c|c|c|c|c|c|c|c|c|c|}
\hline \multirow{2}{*}{$\begin{array}{l}\text { Type of } \\
\text { Variables }\end{array}$} & \multirow[t]{2}{*}{ Variables } & \multirow[t]{2}{*}{ Qualification of Variables } & \multicolumn{7}{|c|}{$\begin{array}{l}\text { Consistency in Relation to the MCDA Tools in Relation to the } \\
\text { Expected Qualification }\end{array}$} \\
\hline & & & ELECTRE & MAUT & ANP & MAC & AHP & TOPSIS & PROMETHEE \\
\hline \multirow{15}{*}{ Exogenous } & \multirow{4}{*}{$\begin{array}{l}\text { Number of } \\
\text { evaluation } \\
\text { elements }\end{array}$} & $\begin{array}{l}\text { Limited number of criteria } \\
\text { and sub-criteria and a small } \\
\text { number of alternatives }\end{array}$ & 0 & 0 & 0 & 0 & 0 & 0 & 0 \\
\hline & & $\begin{array}{l}\text { Limited number of criteria } \\
\text { and sub-criteria and a large } \\
\text { number of alternatives }\end{array}$ & 0 & 0 & 0 & 0 & 0 & 0 & 0 \\
\hline & & $\begin{array}{l}\text { Large number of criteria and } \\
\text { sub-criteria and a small } \\
\text { number of alternatives }\end{array}$ & 0 & 0 & 0 & 0 & 0 & 0 & 0 \\
\hline & & $\begin{array}{l}\text { Large number of criteria and } \\
\text { sub-criteria and a large } \\
\text { number of alternatives }\end{array}$ & 0 & 0 & 0 & 1 & 0 & 1 & 1 \\
\hline & \multirow{3}{*}{$\begin{array}{l}\text { Typology of } \\
\text { indicators }\end{array}$} & Quantitative & 0 & 0 & 0 & 0 & 0 & 0 & 0 \\
\hline & & Qualitative & 0 & 0 & 0 & 0 & 0 & 0 & 0 \\
\hline & & Mixed & 1 & 0 & 1 & 1 & 1 & 1 & 1 \\
\hline & \multirow{3}{*}{$\begin{array}{l}\text { Stakeholders } \\
\text { to be } \\
\text { included in } \\
\text { the decision } \\
\text { process }\end{array}$} & P.P. not activated & 0 & 0 & 0 & 0 & 0 & 0 & 0 \\
\hline & & $\begin{array}{l}\text { P.P. activated with a limited } \\
\text { and specialized number of } \\
\text { stakeholder }\end{array}$ & 0 & 0 & 0 & 0 & 0 & 0 & 0 \\
\hline & & $\begin{array}{l}\text { P.P. activated with a } \\
\text { significant number of } \\
\text { stakeholder preferably } \\
\text { organized in categories }\end{array}$ & 1 & 1 & 1 & 1 & 1 & 1 & 1 \\
\hline & \multirow{3}{*}{$\begin{array}{l}\text { Expected } \\
\text { solution }\end{array}$} & $\begin{array}{l}\text { A better overall alternative } \\
\text { definition for the purpose; } \\
\text { The ideal alternative } \\
\text { definition closest to the lens }\end{array}$ & 0 & 0 & 0 & 0 & 0 & 0 & 0 \\
\hline & & $\begin{array}{l}\text { A better overall alternative } \\
\text { definition for the purpose }\end{array}$ & 0 & 1 & 1 & 1 & 1 & 0 & 1 \\
\hline & & $\begin{array}{l}\text { The ideal alternative } \\
\text { definition closest to the lens }\end{array}$ & 0 & 0 & 0 & 0 & 0 & 0 & 0 \\
\hline & \multirow{2}{*}{$\begin{array}{l}\text { Technical } \\
\text { support of a } \\
\text { Decision Aid } \\
\text { Specialist }\end{array}$} & Yes (advisable) & 1 & 1 & 1 & 1 & 0 & 0 & 0 \\
\hline & & No (not necessary) & 0 & 0 & 0 & 0 & 0 & 0 & 0 \\
\hline \multirow{16}{*}{ Endogenous } & \multirow{3}{*}{$\begin{array}{l}\text { Type of } \\
\text { decision } \\
\text { making } \\
\text { problems }\end{array}$} & Sorting & 0 & 0 & 0 & 0 & 0 & 0 & 0 \\
\hline & & Description & 0 & 0 & 0 & 0 & 0 & 0 & 0 \\
\hline & & Ranking/Choice & 1 & 1 & 1 & 1 & 1 & 1 & 1 \\
\hline & \multirow{3}{*}{$\begin{array}{l}\text { Solution } \\
\text { approach }\end{array}$} & Outranking approach & 0 & 0 & 0 & 0 & 0 & 0 & 0 \\
\hline & & Full aggregation approach & 0 & 1 & 1 & 1 & 1 & 0 & 0 \\
\hline & & $\begin{array}{l}\text { Goal, aspiration or reference } \\
\text { level approach }\end{array}$ & 0 & 0 & 0 & 0 & 0 & 1 & 0 \\
\hline & \multirow{7}{*}{$\begin{array}{l}\text { Implementation } \\
\text { procedure }\end{array}$} & $\begin{array}{l}\text { Preference thresholds, } \\
\text { indifference thresholds, veto } \\
\text { thresholds }\end{array}$ & 0 & 0 & 0 & 0 & 0 & 0 & 0 \\
\hline & & $\begin{array}{l}\text { Preference thresholds, } \\
\text { indifference thresholds }\end{array}$ & 0 & 0 & 0 & 0 & 0 & 0 & 1 \\
\hline & & Utility function & 0 & 0 & 0 & 0 & 0 & 0 & 0 \\
\hline & & $\begin{array}{l}\text { Pairwise comparison on } \\
\text { rational scale and } \\
\text { interdependencies }\end{array}$ & 0 & 0 & 0 & 0 & 0 & 0 & 0 \\
\hline & & $\begin{array}{l}\text { Pairwise comparison on } \\
\text { interval scale }\end{array}$ & 0 & 0 & 0 & 0 & 0 & 0 & 0 \\
\hline & & $\begin{array}{l}\text { Pairwise comparison on } \\
\text { rational scale }\end{array}$ & 0 & 0 & 0 & 0 & 0 & 0 & 0 \\
\hline & & $\begin{array}{l}\text { Ideal option and anti-ideal } \\
\text { option }\end{array}$ & 0 & 0 & 0 & 0 & 0 & 1 & 0 \\
\hline & \multirow{3}{*}{ Input level } & High & 0 & 1 & 1 & 1 & 1 & 0 & 0 \\
\hline & & Medium & 0 & 0 & 0 & 0 & 0 & 0 & 0 \\
\hline & & Low & 0 & 0 & 0 & 0 & 0 & 0 & 0 \\
\hline
\end{tabular}


Table 9. Cont.

\begin{tabular}{|c|c|c|c|c|c|c|c|c|c|}
\hline \multirow{2}{*}{$\begin{array}{c}\text { Type of } \\
\text { Variables }\end{array}$} & \multirow[t]{2}{*}{ Variables } & \multirow[t]{2}{*}{ Qualification of Variables } & \multicolumn{7}{|c|}{$\begin{array}{l}\text { Consistency in Relation to the MCDA Tools in Relation to the } \\
\text { Expected Qualification }\end{array}$} \\
\hline & & & ELECTRE & MAUT & ANP & $\mathrm{MACl}$ & AHP & TOPSIS & PROMETHEE \\
\hline & \multirow{4}{*}{$\begin{array}{l}\text { Output } \\
\text { typology }\end{array}$} & $\begin{array}{l}\text { Partial ordering obtained by } \\
\text { expressing pairwise } \\
\text { preferences degrees }\end{array}$ & 0 & 0 & 0 & 0 & 0 & 0 & 0 \\
\hline & & $\begin{array}{l}\text { Total ordering obtained by } \\
\text { expressing pairwise } \\
\text { preferences degrees }\end{array}$ & 0 & 0 & 0 & 0 & 0 & 0 & 0 \\
\hline & & $\begin{array}{l}\text { Full ordering obtained by } \\
\text { considering the scores }\end{array}$ & 0 & 1 & 1 & 1 & 1 & 0 & 0 \\
\hline & & $\begin{array}{l}\text { Full ordering with score } \\
\text { closest to the aim assumed }\end{array}$ & 0 & 0 & 0 & 0 & 0 & 1 & 0 \\
\hline & \multirow{3}{*}{$\begin{array}{l}\text { Decision } \\
\text { problem } \\
\text { solution }\end{array}$} & $\begin{array}{l}\mathrm{n} \text { categories of alternatives of } \\
\text { equal score but different } \\
\text { behaviour }\end{array}$ & 0 & 0 & 0 & 0 & 0 & 0 & 0 \\
\hline & & $\begin{array}{l}\text { Alternative with the higher } \\
\text { global score }\end{array}$ & 0 & 1 & 1 & 1 & 1 & 0 & 0 \\
\hline & & $\begin{array}{l}\text { Alternative with the closest } \\
\text { score to the ideal solution }\end{array}$ & 0 & 0 & 0 & 0 & 0 & 1 & 0 \\
\hline \multicolumn{3}{|c|}{ Overall suitability index (IS) } & 0.36 & $\begin{array}{l}0.73 \\
\end{array}$ & 0.82 & 0.91 & 0.73 & 0.73 & 0.55 \\
\hline
\end{tabular}

\subsection{MCDA Tools Ordering and Choice of the Tool to be Used (Results)}

The decreasing ordering of the global coherence indicators obtained for each considered MCDA tool identify the MACBETH as the best performing tool according to the objectives of the call. It allows to solve the evaluation problem of choosing the design proposal giving a suitable answer to the aims established by the call (Table 10).

Table 10. Ordering of MCDA tools potentially usable for selecting the best design proposal in the call for tenders for the new services building of the Chamber of Deputies in Rome.

\begin{tabular}{ccc}
\hline MCDA Tool & Overall Suitability Index (IS) & Ranking \\
\hline MACBETH & 0.91 & 1 \\
ANP & 0.82 & 2 \\
MAUT & 0.73 & 3 \\
AHP & 0.73 & 3 \\
TOPSIS & 0.73 & 3 \\
PROMETHEE & 0.55 & 6 \\
ELECTRE & 0.36 & 7 \\
\hline
\end{tabular}

MACABETH is positioned at the top of the order with a consistency index of 0.91 because it has 9 out of 10 properties consistent with the expected qualification; ANP (0.82), MAUT (0.73), AHP (0.73), TOPSIS (0.73) reach a high consistency for solving the decision-making problem related to the case study each being able, but with respectively 9 and 8 out 11 properties consistent with the expected qualifications.

According to an international call for tenders PROMETHEE (0.55) consistency is low and ELECTRE (0.36) is not recommended.

\section{Conclusions}

Given that different MCDA tools, even when given the same input data, can generate different results [13], the proposed procedure must serve as a support for selecting one tool over another [13] in terms of the evaluation problem being addressed.

The proposed approach not only supplements what was proposed by Guitoni et al. [19], but it can also be used by public and private operators as a support for the rationalization of decisions regarding initiatives of settlement transformation $[65,66]$. 
It should be observed that the proposed procedure requires being carried out in contexts where there is a proper knowledge of the MCDA; at least basic knowledge of MCDA tools for its implementation and their potential is required by the process manager, and the process manager must have the right feeling about the relationship between the most suitable MCDA tools in comparison with the suitability and robustness of the results for a specific decision-making problem. The proposed procedure may be difficult to use considering the still low level of MCDA implementation by different workers within the settlement transformation process. For a wider use of the proposed procedure for selecting a MCDA tool, therefore, upgrade could be useful, so that it could be implemented in contexts with low knowledge of the MCDA.

Further development of the proposed procedure may concern: (i) how to identify stakeholders in relation to the decision-making problem to be solved attributing them indices of importance truly representative of their role in decision-making contexts; (ii) how the process manager can reach final decisions (choice of MCDA tool) in contexts characterized by multiple stakeholders; (iii) an in-depth analysis of the selection and use of criteria weighing methods; (iv) the formulation of guidelines to facilitate compilation of the framework of expected properties, even by subjects not particularly qualified in the field of MCDA.

It should also be observed that, when it comes to implementing a MCDA, steps of critical importance include not only the determination of the decision-making problem and the evaluation query (plus the related evaluation objective)—meaning the first phase under the proposed procedure-in deciding which tool should be used, but also: (i) definition of the specific objectives, the criteria and the sub-criteria and the indicators; (ii) the capacity to procure the input data needed to structure the problem; (iii) the capacity to implement and control the analysis, and to develop it in greater depth, in addition to defining the timeframe for resolution of the evaluation query $[67,68]$.

Author Contributions: The paper must be attributed in equal parts to the authors.

Conflicts of Interest: The authors declare no conflict of interest.

\section{References}

1. Marakas, G.M. Decision Support Systems in the 21st Century; Prentice Hall: Upper Saddle River, NJ, USA, 2003; Volume 134.

2. Klapka, J.; Piňos, P. Decision support system for multicriterial R\&D and information systems projects selection. Eur. J. Oper. Res. 2002, 140, 434-446.

3. Belton, V.; Stewart, T. Multiple Criteria Decision Analysis-An Integrated Approach; Kluwer Accademic Press: Boston, MA, USA, 2002.

4. Figueira, J.; Greco, S.; Ehrgott, M. Multiple Criteria Decision Analysis-State of the Art Survay; Springer: New York, NY, USA, 2005.

5. Huang Ivy, B.; Keisler, J.; Linkov, I. Multi-criteria decision analysis in environmental sciences: Ten years of application and trends. Sci. Total Environ. 2011, 409, 3578-3594. [CrossRef] [PubMed]

6. Chung, E.S.; Lee, K.S. Prioritization of water management for sustainability using hydrologic simulation model and multicriteria decision making techniques. J. Environ. Manag. 2009, 90, 1502-1511. [CrossRef] [PubMed]

7. Liu, D.F.; Stewarr, T. Object-oriented decision support system modelling for multicriteria decision making in natural resource management. Comput. Oper. Res. 2004, 31, 985-999. [CrossRef]

8. Qin, X.S.; Huang, G.H.; Chakma, A.; Nie, X.H.; Lin, Q.G. A MCDM-based expert system for climate change impact assessment and adaption planning-A case study for the Georgia Basin, Canada. Expert Syst. Appl. 2008, 34, 2164-2179. [CrossRef]

9. Guarini, M.R.; D’Addabbo, N.; Morano, P.; Tajani, F. Multi-Criteria Analysis in Compound Decision Processes: The AHP and the Architectural Competition for the Chamber of Deputies in Rome (Italy). Buildings 2017, 7,38. [CrossRef] 
10. Guarini, M.R.; Chiovitti, A.; Battisti, F.; Morano, P. An Integrated Approach for the Assessment of Urban Transformation Proposals in Historic and Consolidated Tissues. ICCSA 2017. Lect. Notes Comput. Sci. 2017, 10406, 562-574.

11. Guarini, M.R.; Locurcio, M.; Battisti, F. GIS-Based Multi-criteria Decision Analysis for the "Highway in the Sky". ICCSA 2015. Lect. Notes Comput. Sci. 2015, 9157, 146-161.

12. Haimes Yacov, Y. On the Universality and contributions of Multiple Criteria Decision Making: A systems-based Approach. J. Multi-Criteria Decis. Anal. 2011, 18, 91-99. [CrossRef]

13. Ishizaka, A.; Nemery, P. Multi-Criteria Decision Analisys, Methods and Software; Wiley and Sons Ltd.: Chichester, UK, 2013.

14. Roy, B. Méthodologie Multicritére d'Aide à la Décision; Economica: Paris, France, 1985.

15. Guitoni, A.; Martel, J.M. Tentative guidelines to help choosing an appropriate MCDA method. Eur. J. Oper. Res. 1998, 109, 501-521. [CrossRef]

16. Vincke, P. L'aide Multicritère à la Décision; Université de Bruxelles: Bruxelles, Belgium, 1989.

17. Colson, G.; De Bruyn, C. Models and Methods in Multiple Objectives Decision Making, Models and Methods in Multiple Criteria Decision Making; Pergamon Press: Oxford, UK, 1989.

18. Fishburn, P.C. A survey of multiattribute/multicriterion evaluation theories. In Multiple Criterion Problem Solving; Zionts, S., Ed.; Springer: Heidelberg, Germany, 1978; pp. 181-224.

19. Guitouni, A.; Martel, J.M.; Vincke, P.; North, P.B. A Framework to Choose a Discrete Multicriterion Aggregation Procedure. 1998. Available online: https://pdfs.semanticscholar.org/27d5/ 9c846657268bc840c4df8df98e85de66c562.pdf (accessed on 28 July 2017).

20. Roy, B.; Bouyssou, D. Aide Multicritère à la Décision: Methodes et Cas; Economica: Paris, France, 1993.

21. Keeney, R.L.; Raiffa, H. Decisions with Multiple Objectives: Preferences and Value Trade-Offs; Cambridge University Press: Cambridge, UK, 1993.

22. Roy, B. Classement et choix en presence de points de vue multiples: La méthode ELECTRE. Revue Francaise d'Informatique et de Recherche Opérationnelle 1968, 8, 57-75. [CrossRef]

23. Dyer, J.S. MAUT-Multiattribute utility theory. In Multiple Criteria Decision Analysis: State of the Art Surveys; Springer: New York, NY, USA, 2005; pp. 265-292.

24. Saaty, T.L. Analytic network process. In Encyclopedia of Operations Research and Management Science; Springer: New York, NY, USA, 2001; pp. 28-35.

25. Bana e Costa, C.; Vansnick, J.C. MACBETH: An interactive path to-wards the construction of cardinal value functions. Oper. Res. 1994, 1, 387-500. [CrossRef]

26. Saaty, T. A scaling Method for priorities in herarchical structures. Math. Psychol. 1977, 15, 234-281. [CrossRef]

27. Hwang, C.L.; Yoon, K. Multiple Attribute Decision Making: Methods and Applications; Springer: Heidelberg, Germany; New York, NY, USA, 1981.

28. Brans, J.P.; Vincke, P. Note-A Preference Ranking Organisation Method: The PROMETHEE Method for Multiple Criteria Decision-Making. Manag. Sci. 1985, 31, 647-656. [CrossRef]

29. European Commission. Evaluation Methods for the European Union's External Assistance. Evaluation Tool. 2006. Available online: http:/ / ec.europa.eu/europeaid/sites/devco/files/evaluation-methods-guidancevol4_en.pdf (accessed on 28 July 2017).

30. Seixedo, C.; Tereso, A. A Multicriteria Decision Aid Software Application for selecting MCDA Software using AHP. In Proceedings of the 2nd International Conference on Engineering Optimization, Lisbon, Portugal, 6-9 September 2010; Available online: http:/ / hdl.handle.net/1822/19355 (accessed on 5 October 2017).

31. Battisti, F.; Guarini, M.R. Public interest evaluation in negotiated public-private partnership. Int. J. Multi-Criteria Decis. Mak. 2017, 7, 54-89. [CrossRef]

32. Campbell, J.D.; Jardine, A.K.; McGlynn, J. (Eds.) Asset Management Excellence: Optimizing Equipment Life-Cycle Decisions; CRC Press: Boca Raton, FL, USA, 2016.

33. Guarini, M.R.; Battisti, F. Evaluation and Management of Land-Development Processes Based on the Public-Private. Adv. Mater. Res. 2014, 869-870, 154-161. [CrossRef]

34. Bouyssou, D. Some remarks on the notion of compensation in MCDA. Eur. J. Oper. Res. 1986, 26, $150-160$. [CrossRef]

35. Bouyssou, D. Building criteria: A prerequisite for MCDA. Read. Mult. Criteria Decis. Aid 1990, 58-80. [CrossRef] 
36. Roy, B.; Vanderpooten, D. The European school of MCDA: Emergence, basic features and current works. J. Multi-Criteria Decis. Anal. 1996, 5, 22-38. [CrossRef]

37. Belton, V.; Pictet, J. A framework for group decision using a MCDA model: Sharing, aggregating or comparing individual information? J. Decis. Syst. 1997, 6, 283-303. [CrossRef]

38. Akaa, O.U.; Abu, A.; Giovinazzi, S. Balancing stakeholder views for decision-making in steel structural fire design. In Proceedings of the International Conference on Performance-based and Life-cycle Structural Engineering, School of Civil Engineering, Brisbane, Australia, 9-11 December 2015; pp. 983-992.

39. Lahdelma, R.; Salminen, P.; Hokkanen, J. Using Multicriteria Methods in Environmental Planning and Management. Environ. Manag. 2000, 26, 595-605. [CrossRef] [PubMed]

40. Li, Y.; Thomas, M.A. A Multiple Criteria Decision Analysis (MCDA) Software selection Framework. In Proceedings of the 47th Hawaii International Conference on System Science (HICSS), Waikoloa, HI, USA, 6-9 January 2014; pp. 1084-1094.

41. Kaspar, R.; Ossadnik, W. Evaluation of AHP software from a management accounting perspective. J. Model. Manag. 2013, 8, 305-319.

42. Make It Rational AHP Software. Available online: http:/ / makeitrational.com/analytic-hierarchy-process/ ahp-software (accessed on 5 October 2017).

43. Expert Choice. Available online: http://www.expertchoice.com (accessed on 5 October 2017).

44. Super Decisions CDS. Available online: https://superdecisions.com (accessed on 5 October 2017).

45. Right Choice. Ventana Systems UK. Available online: http://www.ventanasystems.co.uk/services/ software/rightchoice/ (accessed on 5 October 2017).

46. M-MACBETH Software. Available online: http://www.m-macbeth.com (accessed on 5 October 2017).

47. Smart Picker Pro: The Desktop Application. Available online: http://www.smart-picker.com/products (accessed on 5 October 2017).

48. Electre III-IV Software. Available online: http://www.lamsade.dauphine.fr/spip.php?rubrique64\&lang=fr (accessed on 5 October 2017).

49. Triptych: TOPSIS. Available online: http://www.stat-design.com/Software/TOPSIS.html (accessed on 5 October 2017).

50. Salet, W.G.; Thornley, A.; Kreukels, A. (Eds.) Metropolitan Governance and Spatial Planning: Comparative Case Studies of European City-Regions; Taylor \& Francis: Oxford, UK, 2003.

51. Bouyssou, D.; Perny, P. Ranking methods for valued preference relations: A characterization of a method based on leaving and entering flows. Eur. J. Oper. Res. 1992, 61, 186-194. [CrossRef]

52. Saaty, T. The Analytic Hierarchy Process; Mcgraw Hill: New York, NY, USA, 1980.

53. Bana e Costa, C.; Vansnick, J. On the mathematical foundations of MACBETH. In Multiple Criteria Decision Analysis: State of the Art Surveys; Springer: New York, NY, USA, 2005; pp. 409-442.

54. Lai, Y.J.; Hwang, C.L. Fuzzy multiple objective decision making. In Fuzzy Multiple Objective Decision Making; Springer: Berlin/Heidelberg, Germany, 1994; Volume 404, pp. 139-262.

55. Hwang, C.L.; Paidy, S.R.; Yoon, K.; Masud, A.S.M. Mathematical programming with multiple objectives: A tutorial. Comput. Oper. Res. 1980, 7, 5-31. [CrossRef]

56. Behzadian, M.; Otaghsara, S.K.; Yazdani, M.; Ignatius, J. A state-of the-art survey of TOPSIS applications. Expert Syst. Appl. 2012, 39, 13051-13069. [CrossRef]

57. Baudry, G.; Macharis, C.; Vallée, T. Range-based Multi-Actor Multi-Criteria Analysis: A combined method of Multi-Actor Multi-Criteria Analysis and Monte Carlo simulation to support participatory decision making under uncertainty. Eur. J. Oper. Res. 2018, 264, 257-269. [CrossRef]

58. Ascough, J.C., II; Maier, H.R.; Ravalico, J.K.; Strudley, M.W. Future research challenges for incorporation of uncertainty in environmental and ecological decision-making. Ecol. Model, the Importance of Uncertainty and Sensitivity Analysis in Process-based Models of Carbon and Nitrogen Cycling in Terrestrial Ecosystems with Particular Emphasis on Forest Ecosystems. In A Workshop Organized by the International Society for Ecological Modelling (ISEM), Proceedings of the Third Biennal Meeting of the International Environmental Modelling and Software Society (IEMSS), Burlington, VT, USA, 9-13 August 2006; Ecological Modelling Elsevier: Amsterdam, the Netherlands, 2008; Volume 219, pp. 383-399. [CrossRef]

59. Salo, A.; Hämäläinen, R.P. Multicriteria Decision Analysis in Group Decision Processes. In Handbook of Group Decision and Negotiation, Advances in Group Decision and Negotiation; Kilgour, D.M., Eden, C., Eds.; Springer Science \& Business Media: Dordrecht, the Netherlands, 2010; pp. 269-283. 
60. Wang, J.-J.; Jing, Y.-Y.; Zhang, C.-F.; Zhao, J.-H. Review on multi-criteria decision analysis aid in sustainable energy decision-making. Renew. Sustain. Energy Rev. 2009, 13, 2263-2278. [CrossRef]

61. Saaty, T.L.; Vargas, L.G. Models, Methods, Concepts \& Applications of the Analytic Hierarchy Process; Springer Science \& Business Media: Dordrecht, the Netherlands, 2012; Volume 175.

62. Ribeiro, F.; Ferreira, P.; Araújo, M. Evaluating future scenarios for the power generation sector using a Multi-Criteria Decision Analysis (MCDA) tool: The Portuguese case. Energy 2013, 52, 126-136. [CrossRef]

63. Dulmin, R.; Mininno, V. Supplier selection using a multi-criteria decision aid method. J. Purch. Supply Manag. 2003, 9, 177-187. [CrossRef]

64. Guarini, M.R.; Battisti, F. Benchmarking Multi-criteria Evaluation: A Proposed Method for the Definition of Benchmarks in Negotiation Public-Private Partnerships. ICCSA 2014. Lect. Notes Comput. Sci. 2014, 8581, 208-223.

65. Saaty, T.L.; De Paola, P. Rethinking design and urban planning for the cities of the future. Buildings 2017, 7, 76. [CrossRef]

66. Morano, P.; Tajani, F. The break-even analysis applied to urban renewal investments: A model to evaluate the share of social housing financially sustainable for private investors. Habitat Int. 2017, 59, 10-20. [CrossRef]

67. Guarini, M.R.; Buccarini, C.; Battisti, F. Technical and Economic Evaluation of a Building Recovery by Public-Private Partnership in Rome (Italy). Green Energy and Technology. In Appraisal: From Theory to Practice; Stanghellini, S., Morano, P., Bottero, M., Oppio, A., Eds.; Springer: Berlin, Germany, 2017; pp. 101-115.

68. Nesticò, A.; Sica, F. The sustainability of urban renewal projects: A model for economic multi-criteria analysis. J. Prop. Invest. Financ. 2017, 35, 397-409. [CrossRef]

(C) 2017 by the authors. Licensee MDPI, Basel, Switzerland. This article is an open access article distributed under the terms and conditions of the Creative Commons Attribution (CC BY) license (http:/ / creativecommons.org/licenses/by/4.0/). 